(2) Open Access Full Text Article

\title{
Pyrrolyl thiadiazoles as Mycobacterium tuberculosis inhibitors and their in silico analyses
}

This article was published in the following Dove Press journal:

Research and Reports in Medicinal Chemistry

28 April 2015

Number of times this article has been viewed

\author{
Shrinivas D Joshi' \\ Uttam A More ${ }^{1,2}$ \\ Shailesh Sorathiya' \\ Deepshikha Koli' \\ Tejraj M Aminabhavi' \\ 'Novel Drug Design and Discovery \\ Laboratory, Department of \\ Pharmaceutical Chemistry, Soniya \\ Education Trust's College of \\ Pharmacy, Dharwad, India; ${ }^{2}$ Centre \\ for Research and Development, Prist \\ University, Thanjavur, Tamil Nadu, \\ India
}

\begin{abstract}
A novel series of pyrrolyl thiadiazoles was synthesized and tested for antimycobacterial activity against the Mycobacterium tuberculosis $\mathrm{H}_{37} \mathrm{Rv}$ strain, using the microplate Alamar blue assay method. Molecular docking and in vitro minimum inhibitory concentration assays revealed that these molecules can be primarily screened for ENR inhibition, using the score values and H-bond interactions with amino acid residues Tyr158, Met98, and cofactor $\mathrm{NAD}^{+}$, which are the key interactions. For most of the molecules, hydrophobic interaction is the key factor affecting their antitubercular activity. The activity of $-\mathrm{OCH}_{3},-\mathrm{NO}_{2},-\mathrm{F}$, pyridine, and sulfonamide substituted derivatives was better than that of $-\mathrm{CH}_{3},-\mathrm{NH}_{2},-\mathrm{Cl}$, and $-\mathrm{Br}$ substituted derivatives, as per experimental and docking studies. Molecular modeling studies are in agreement with their biological evaluations.
\end{abstract}

Keywords: pyrroles, antitubercular activity, Surflex-Docking, enoyl-ACP reductase

\section{Introduction}

Among the many infectious diseases, tuberculosis (TB) is one of the major ones caused by Mycobacterium tuberculosis. ${ }^{1}$ Since 1993, the World Health Organization has identified TB as a global health emergency, with more than nine million new cases arising every year and an annual death toll of around 1.8 million people worldwide. The treatment of TB is a major problem, in view of the emergence of monodrug- and multidrug-resistant strains of $M$. tuberculosis. ${ }^{2}$ Thus, there is an increasing need to develop novel anti-TB agents for the effective treatment of TB with reduced toxicity and enhanced activity against multidrug-resistance (MDR) strains for a short duration of therapy.

There are two discrete enzymes in the biosynthesis of fatty acids in bacteria; namely, fatty acid synthase (FAS) I and II. Type II fatty acid elongation system (FAS-II) of bacteria, in which reactions are catalyzed by different enzymes and each is encoded by a discrete gene, constitutes an attractive target for inhibition, as these enzymes differ significantly from type I FAS (FAS-I) in mammalians, in which enzymatic activities are encoded in one or two multifunctional polypeptides. $M$. tuberculosis possesses both FAS-I and FAS-II systems, of which FAS-I is responsible for bimodal distribution of products, ${ }^{3,4}$ centered on $\mathrm{C} 16$ and $\mathrm{C} 24-\mathrm{C} 26$, but the FAS-II system prefers $\mathrm{C} 16$ as the starting substrate, which can extend ${ }^{5}$ up to C56, indicating that mycobacterial FAS-II uses the products of FAS-I as the primers to extend fatty acyl chain lengths even further. The longer chain products of FAS-II are the precursors of mycolic acids, and both the systems provide precursors for biosynthesis of mycolic acids, which contain
Novel Drug Design and Discovery Laboratory, Department of Pharmaceutical Chemistry, Soniya Education Trust's College of Pharmacy, Sangolli Rayanna Nagar, Dharwad 580 002, India

Tel +91 9986151953

Fax +91 8362467190

Email shrinivasdj@rediffmail.com
Research and Reports in Medicinal Chemistry 20I5:5 I-20

(c) (i) (8) $\odot 2015$ Joshi et al. This work is published by Dove Medical Press Limited, and licensed under Creative Commons Attribution - Non Commercial (unported, v3.0)

Dovepress

http://dx.doi.org//0.2147/RRMC.S80395
License. The full terms of the license are available at http://creativecommons.org/licenses/by-nc/3.0/. Non-commercial uses of the work are permitted without any further permission from Dove Medical Press Limited, provided the work is properly attributed. Permissions beyond the scope of the License are administered by Dove Medical Press Limited. Information on how to request permission may be found at: http://www.dovepress.com/permissions.php 
very long chain fatty acids that are the prominent and essential components of the mycobacterial cell wall.,

The nicotinamide adenine dinucleotide-dependent enoylacyl carrier protein reductase encoded by Mycobacterium gene inh $A$ has been validated as the primary molecular target of the frontline antitubercular drug, isoniazid. ${ }^{8}$ Recent studies have demonstrated that InhA is also the target for the secondline antitubercular drug ethionamide. ${ }^{9}$ As a prodrug, isoniazid must be activated by the mycobacterial catalase-peroxidase $\mathrm{KatG}$ into its acyl radical active form. However, some inhibitors can target InhA directly, without a requirement for activation similar to pyrazole derivatives, indole-5-amides, ${ }^{10}$ alkyl diphenyl ethers, ${ }^{11}$ and pyrrolidine carboxamides. ${ }^{12}$ During our study, it was found that the InhA inhibitor, that is, 1-cyclohexyl- $N$-(3,5-dichlorophenyl)-5-oxopyrrolidine3-carboxamide (pyrrolidine carboxamide or 641), contains three hydrophobic moieties, cyclohexyl, oxopyrrolidine, and 3,5-dichlorophenyl, which can be mapped by new designed molecules containing pyrrole, 1,3,4-thiadiazole, and substituted phenyl (see details in Figure S1). These findings prompted us to select InhA as the target for our newly designed molecules. Hence, by considering the nicotinamide adenine dinucleotide-dependent enoyl-acyl carrier protein reductase as the target receptor, we have performed molecular docking studies and screening for the supportive coordination between in silico studies and the in vitro results.

Pyrroles conform to an important class of heterocycles having a wide range of biological activities, ${ }^{13}$ such as antitubercular, antiinflammatory, antiviral, and antiproliferative activities. The versatile and eminent biological profiles of 1,3,4-thiadiazoles and their analogs are well known. ${ }^{14}$ Because of the presence of a toxophoric $\mathrm{N}=\mathrm{C}-\mathrm{S}$ moiety, 1,3,4-thiadiazoles exhibit a broad spectrum of biological activities. Recent literature suggests that 1,3,4thiadiazole derivatives exhibit antibacterial and antitubercular activities. ${ }^{15,16}$ On the basis these facts, and supported by the literature findings, ${ }^{17-22}$ we propose synthesizing and testing the biological activities of a new type of pyrrolyl thiadiazole derivatives from 2-amino-5-substituted phenyl1,3,4-thiadiazoles, with a hope that these new molecules would exhibit enhanced biological activity because of the presence of pharmacologically active heterocyclic and aromatic substituents. In our previous study, we have synthesized various heterocycles as antiinfective agents (Figure 1), where we determined that pyrrole and thiadiazole derivatives are good antitubercular and antimicrobial agents. ${ }^{23-27}$ Keeping this in mind, we report here new prototype hybrid molecules (Figure 2 ) by combining pyrrole and thiadiazole

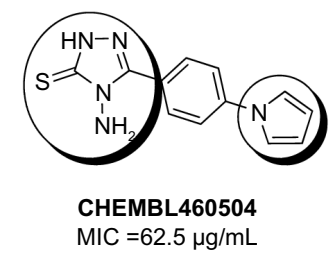

4-amino-3-(4-pyrrol-1-ylphenyl)-1H-1,2,4-triazole-5-thione

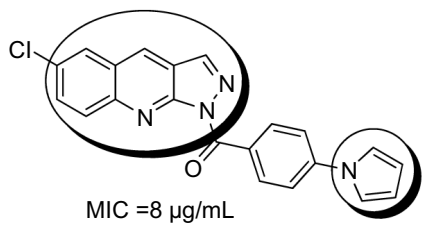

4-(1H-pyrrol-1-yl)phenyl (6-chloro-1H-pyrazolo [3,4-b] quinolin-1-yl)methanone
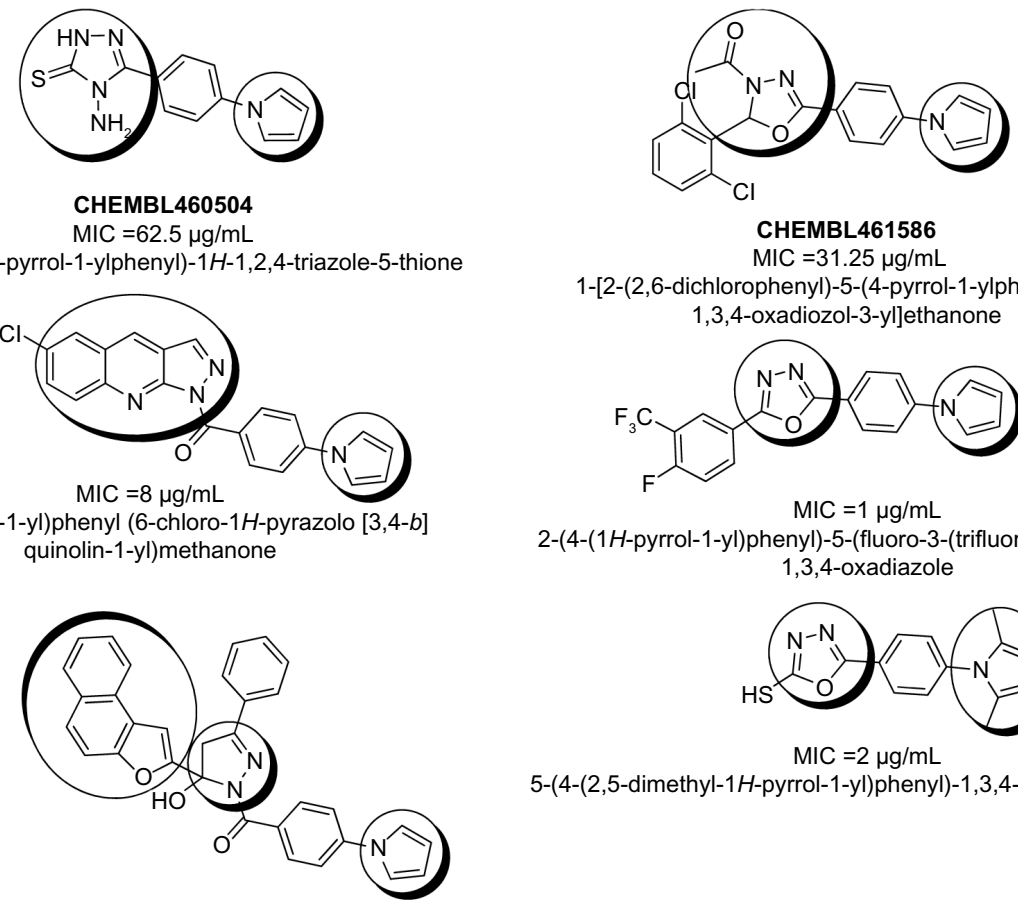

CHEMBL461586

$\mathrm{MIC}=31.25 \mu \mathrm{g} / \mathrm{mL}$

1-[2-(2,6-dichlorophenyl)-5-(4-pyrrol-1-ylphenyl)-2H1,3,4-oxadiozol-3-yl]ethanone

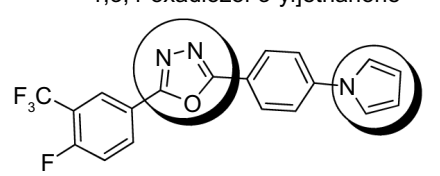

$\mathrm{MIC}=1 \mu \mathrm{g} / \mathrm{mL}$

2-(4-(1H-pyrrol-1-yl)phenyl)-5-(fluoro-3-(trifluoromethyl)phenyl)1,3,4-oxadiazole

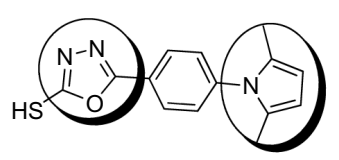

$\mathrm{MIC}=2 \mu \mathrm{g} / \mathrm{mL}$

5-(4-(2,5-dimethyl-1H-pyrrol-1-yl)phenyl)-1,3,4-oxadiazole-2-thiol

(4-(1H-pryrrol-1-yl)phenyl(5-hydroxy-5-naphthol[2,1-b]furan-2-yl)3-phenyl-4,5-dihydro-1H-pyrazol-1-yl)methanone

Figure I Reported molecules; pyrrole connected to heterocycles (oxadiazole, triazole, pyrazolo[3,4-b]quinolin-I-yl, naphtha[2, I-b]furan-2-yl) through phenyl bridge. Abbreviations: CHEMBL, chemical database of bioactive molecules with drug-like properties; MIC, minimum inhibitory concentration. 


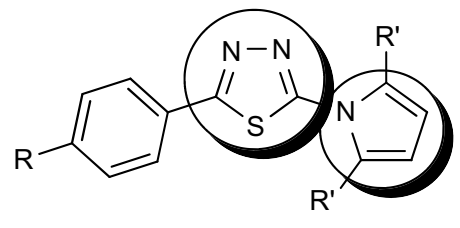

2-(2,5-substituted-1H-pyrrol-1-yl)-5(4-substituted phenyl)-1,3,4-thiadiazoles

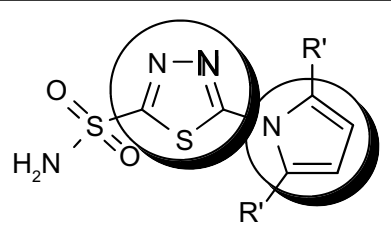

5-(2,5-substituted-1H-pyrrol-1-yl)1,3,4-thiadiazoles-2-sulfonamides

Figure 2 Designed molecules; pyrrole connected to thiadiazole directly.

moieties and investigating their in vitro antitubercular activity, as well as Surflex-Docking analyses. The present work, therefore reports on the structure and ligand-based drug design and discovery processes. The crystallographic 3D structural information of the biomolecular targets offers tremendous opportunities for establishing such novel drug design strategies to accelerate the drug discovery process. To accomplish this, docking simulation was performed to predict the binding orientation of small molecules to protein targets to predict their affinity and activity. ${ }^{28}$

\section{Results and discussion Synthesis and spectral studies}

Compounds $4 \mathrm{a}-4 \mathrm{i}, 5 \mathrm{a}-5 \mathrm{i}, 8 \mathrm{a}$, and $8 \mathrm{~b}$ were synthesized as per Figures 3 and 4. In Figure 3, the 2-amino-5-(4-substituted phenyl)-1,3,4-thiadiazoles (3a-3i) were synthesized by condensation of aromatic acids ( $1 \mathrm{a}-\mathrm{i})$ with thiosemicarbazide (2) in the presence of a dehydration agent $\left(\mathrm{POCl}_{3}\right)$. The 2-amino-5-sulfonamido-1,3,4-thiadiazole (7) was obtained by the hydrolysis of acetazolamide (6) in concentrated $\mathrm{HCl}$ (Figure 4). The Paal-Knorr pyrrole synthesis involving<smiles>NNC(=S)Nc1cccc(Br)c1</smiles>

$3 a-\mathbf{i}$

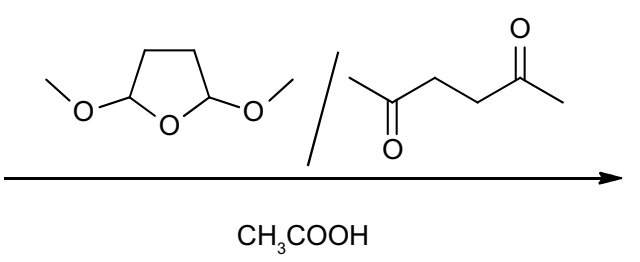<smiles>[R]c1ccc([R])n1-c1nnc([AlH2])s1</smiles>

$4 a-i$ and $5 a-i$

Where Ar,<smiles>[CH]c1ccccc1</smiles><smiles>[B]c1ccc(OC)cc1</smiles><smiles>C#Cc1ccc(Cl)cc1</smiles><smiles>[C]c1ccc([N+](=O)[O-])cc1</smiles><smiles>[CH]c1ccc(Br)cc1</smiles><smiles>Cc1ccc([I-])cc1</smiles><smiles>[C-]c1ccc(N)cc1</smiles><smiles>Fc1ccc([PH])cc1</smiles><smiles>[I-]c1cccnc1</smiles>

4a-i $\mathrm{R}=\mathrm{H}, \mathbf{5 a}-\mathbf{i} \mathrm{R}=\mathrm{CH}_{3}$

Figure 3 Synthetic route for 2-substituted pyrrole-I H-5-(4-substituted phenyl)-1,3,4-thiadiazoles. 

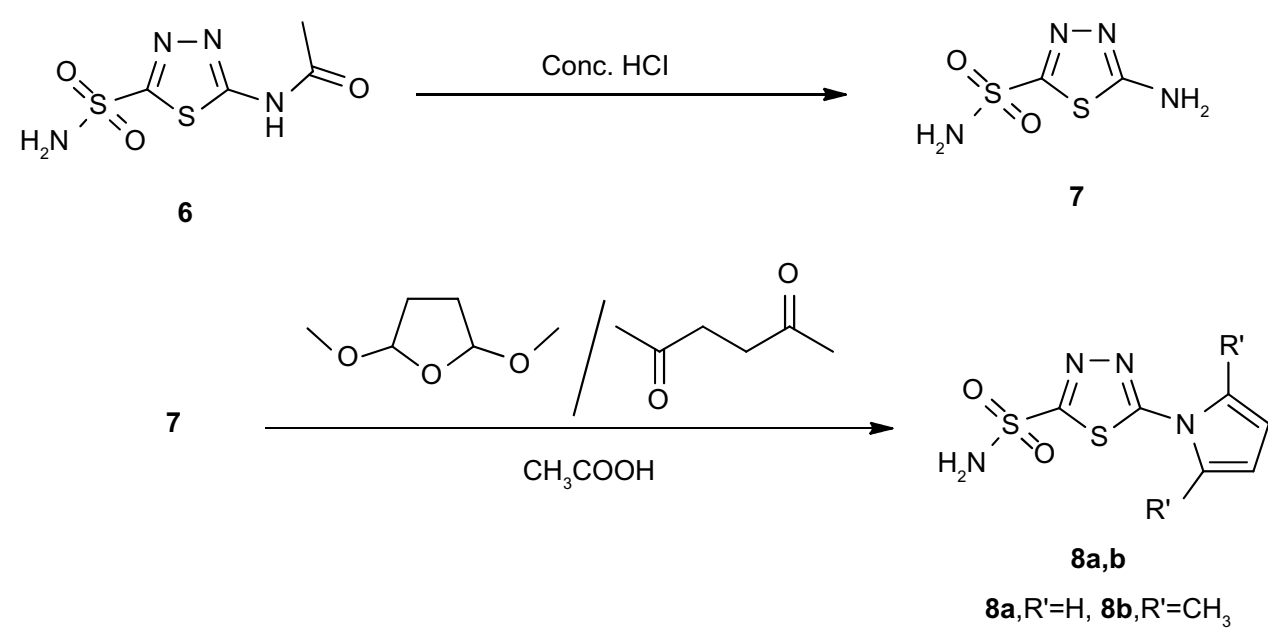

Figure 4 Synthetic route for 2-substituted pyrrole- I H-5-sulfonamido-I,3,4-thiadiazoles. Abbreviation: Conc., concentration.

the reaction of 1,4-dicarbonyl (2,5-hexanedione) or 2,5dimethoxy tetrahydrofuran with amines is among the most classical methods of heterocyclic pyrrole ring synthesis. Pyrrole $(4 a-4 i, 8 a)$ and 2,5-dimethyl pyrrole $(5 a-5 i, 8 b)$ rings have been constructed by using the free amino group at the second position of 1,3,4-thiadiazoles $(3 a-3 i, 7)$ in the presence of dry glacial acetic acid.

Structures of the compounds were assigned by the spectral and analytical data; namely, Fourier transform infrared spectroscopy (FTIR), nuclear magnetic resonance (NMR), and mass spectroscopy, as reported in the experimental section. In the ${ }^{1} \mathrm{H}$ NMR spectrum of $4 \mathrm{c}$, four protons of pyrrole moiety resonate as two doublet of doublets at $\delta 7.43$ and $\delta 6.40$, whereas four protons of phenyl moiety resonate as two doublets at $\delta 7.93$ and $\delta$ 7.56. The mass spectrum of $4 \mathrm{c}$ showed the molecular ion peak at a mass-to-charge ratio $(\mathrm{m} / \mathrm{z})$ of 261.78 that confirmed its molecular weight.

The disappearance of the $\mathrm{NH}_{2}$ stretching band in the FTIR spectrum of 5c confirmed the formation of dimethyl pyrrole. The ${ }^{1} \mathrm{H}$ NMR spectrum of $5 \mathrm{c}$ showed a singlet at $\delta$ 2.25 that was accounted for two methyl groups. The $\mathrm{C}_{3}$ and $\mathrm{C}_{4}$ protons of pyrrole ring appeared as a singlet at $\delta 5.94$. The four protons of phenyl moiety resonate as two doublets at $\delta 8.02$ and $\delta 7.60$.

Electron impact mass spectra showed accurate molecular ion peaks at m/z 226.97, 257.49, 261.78 (263.78), 272.31 (273.31), 306.09 (308.09), 241.17, 242.28, 245.37, $228.11,255.01,285.11,289.05$ (291.05), 300.23 (301.23), 332.56 (334.56), 269.03, 270.17, 273.01, 256.13, 229.07, and 258.19 for compounds $4 \mathrm{a}-4 \mathrm{i}, 5 \mathrm{a}-5 \mathrm{i}$, and $8 \mathrm{a}-8 \mathrm{~b}$, respectively.

\section{Antitubercular activity}

The results of antitubercular activities (expressed in minimum inhibitory concentration [MIC], which was converted to $\mathrm{pMIC}=-\log \mathrm{MIC}$, calculated by Sybyl-X 2.0 software) of the compounds against selected $M$. tuberculosis $\mathrm{H}_{37} \mathrm{Rv}$ are illustrated in Table 1. The compounds (4a-4i, 5a-5i, and $8 \mathrm{a}-8 \mathrm{~b})$ showed the activities against mycobacteria, with the MIC values ranging from 12.5 to $100 \mu \mathrm{g} / \mathrm{mL}$ (pMIC 4.9034.000). Compounds 4b, 5b, and $5 \mathrm{~d}$ inhibited mycobacterial growth effectively compared with others in the series, showing MIC values of $12.5 \mu \mathrm{g} / \mathrm{mL}$ (pMIC 4.903), followed by compounds 4d, 4h, 4i, 5h, 5i, 8a, and 8 b at $25 \mu \mathrm{g} / \mathrm{mL}$ (pMIC 4.602). The compounds with $-\mathrm{OCH}_{3},-\mathrm{NO}_{2},-\mathrm{F}$, pyridine, and sulphonamide substituents have shown better antitubercular activities than others. In these compounds, all the functional groups are $\mathrm{H}$-bond acceptors, which might be responsible for achieving a better inhibitory action on M. tuberculosis.

\section{Protein quality and active site identification}

Ramachandran plots, which give an indication of the quality of the model, as well as hydrophobicity plots (Figures 5 and $6 \mathrm{~A}$ and $\mathrm{B}$ ), were obtained at the end of the minimization. In Figure 5, red color violation 2 means PRO in the generously allowed region and non-GLY in the disallowed region, and a magenta color violation 1 means PRO in the allowed region and non-GLY in the generously allowed region, but a blue color violation 0 means PRO in the favored region, non-GLY in the favored or allowed region, and GLY in any region. Almost $98 \%$ of the residues were found in the most favored region, but $2 \%$ were found in the additional allowed regions; $0 \%$ were found in the disallowed regions. As shown 
Table I Antimycobacterial activity (MIC values in $\mu \mathrm{g} / \mathrm{mL}$ and PMIC values are -logMIC) for pyrrolyl thiadiazole derivatives $(4 a-4 i, 5 a-5 i$, and $8 a-8 b)$

\begin{tabular}{|c|c|c|}
\hline $\mathrm{Ar}$ & nd $5 \mathrm{a}-\mathrm{i}$ & \\
\hline Compound & $\begin{array}{l}\text { Mycobacterium tuberculosis } \\
\left.\mathrm{H}_{37} \mathrm{Rv} \text { MIC ( } \mu \mathrm{g} / \mathrm{mL}\right)\end{array}$ & $\begin{array}{l}\text { pMIC* } \\
(-\log M I C)\end{array}$ \\
\hline $4 a$ & 100 & 4.000 \\
\hline $4 b$ & 12.5 & 4.903 \\
\hline $4 c$ & 100 & 4.000 \\
\hline $4 d$ & 25 & 4.602 \\
\hline $4 e$ & 100 & 4.000 \\
\hline $4 f$ & 50 & 4.301 \\
\hline $4 g$ & 50 & 4.301 \\
\hline $4 \mathrm{~h}$ & 25 & 4.602 \\
\hline $4 i$ & 25 & 4.602 \\
\hline $5 a$ & 100 & 4.000 \\
\hline $5 b$ & 12.5 & 4.903 \\
\hline $5 c$ & 100 & 4.000 \\
\hline $5 d$ & 12.5 & 4.903 \\
\hline $5 e$ & 100 & 4.000 \\
\hline $5 f$ & 50 & 4.301 \\
\hline $5 g$ & 50 & 4.301 \\
\hline $5 \mathrm{~h}$ & 25 & 4.602 \\
\hline $5 i$ & 25 & 4.602 \\
\hline $8 a$ & 25 & 4.602 \\
\hline $8 b$ & 25 & 4.602 \\
\hline Isoniazid & 0.25 & 6.6021 \\
\hline
\end{tabular}

Note: *Values calculated by Sybyl-X 2.0 software.

Abbreviation: MIC, minimum inhibitory concentration.

in Figure 6A, analyzing the shape of the plot gives information about partial structure of the protein. For instance, if a stretch of about 20 amino acids shows positive for hydrophobicity, these amino acids may be part of alpha-helix spanning across a lipid bilayer, which is composed of hydrophobic fatty acids. On the converse, amino acids with high hydrophilicity indicate these residues are in contact with the solvent or water and are, therefore, likely to reside on the outer surface of the protein (scores are given in Table S1).

The active site at InhA was identified using SiteID or Protomol generation suite. The SiteID method generated many possible spheres of radius of water inside the protein molecules that were in search of the largest space or cluster available, which could be identified as an active site (Figure 7). A flood-fill algorithm, similar to the one implemented in CAVITY, was used ${ }^{29}$ for each solvent molecule in the pocket, and all atoms in the protein lying within the specified distance (default $=3 \AA$ ) were considered. This generated four sites: site 1, yellow, Gly96, Met103, Gly104,

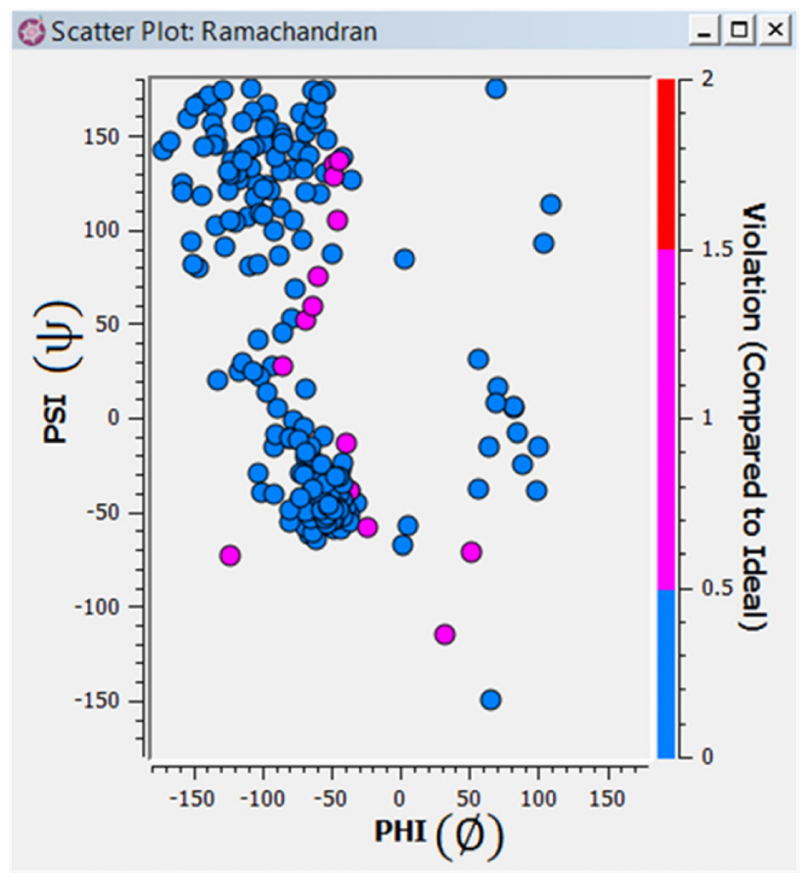

Figure 5 Ramachandran plot for analysis of residue shows the PHI (Ф) and PSI $(\psi)$ torsion angles for all residues in structure; $\Phi$ values on $\mathrm{X}$-axis and $\psi$ values on $\mathrm{Y}$-axis.

Notes: Red color indicates Proline (PRO) in generously allowed region and nonGlycine (GLY) in disallowed region; magenta color indicates PRO in allowed region and non-GLY in generously allowed region; blue color indicates PRO in favored region, non-GLY in favored or allowed region and GLY in any region.

Pro156, Ala157, Tyr158, Met161, Met199, Ile202, Ile215, Leu218, and NAD500; site 2, green, Ile15, Ile16, NAD500, Leu38, Thr39, Gly40, Phe41, Ile47, Leu60, and Leu63; site 3, cyan, Phe149, Asp150, Met155, Ala190, Ala191, Trp222, and Asp261; and site 4, white, Ser19, His24, and Ala235. In the case of the Protomol method, Protomols can be produced by one of three routes: automatic: Surflex-Dock finds the largest cavity in the receptor protein; ligand-based: by a ligand in the same coordinate space as the receptor; residue-based: by specified residues in the receptor. Thus, a Protomol can be generated automatically or be defined on the basis of a cognate ligand or known active site. The sites generated were compared with the active site of the template and we found that site 1 (yellow region) is highly conserved. In this article, a Protomol generated by the ligand-based approach was identical to SiteID site 1. Hence, we used the ligand-based generated Protomol for further study (Figure 8A). However, Figure 8B gives a clear picture of the obtained active site.

Surflex-Dock was applied to studying the molecular docking, which uses an empirical scoring function and a patented search engine to dock the ligands into the protein's binding site. ${ }^{30,31}$ In the docking procedure, ten binding poses per ligand were obtained, and the binding pose with the highest 

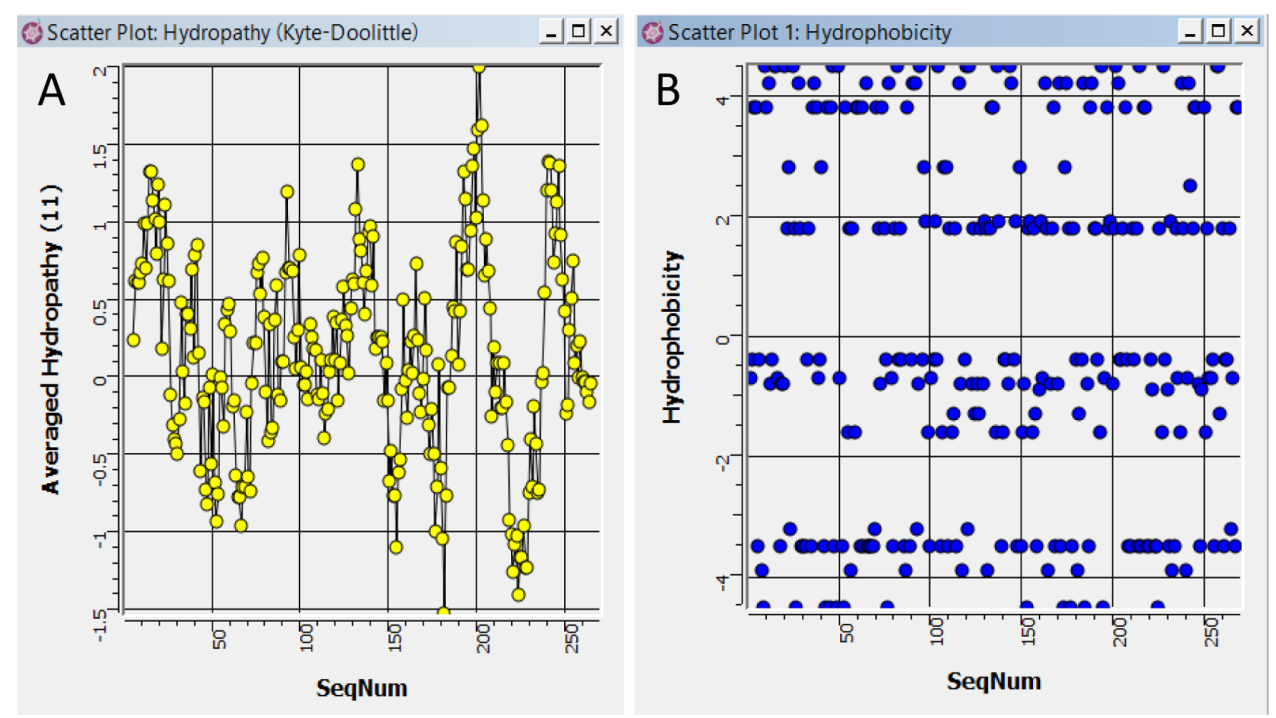

Figure 6 (A) Hydropathy index averaged over a moving window of eleven residues.

(B) Hydrophobicity at each residue.

total score was considered for ligand-receptor interactions. Optimization of the results was carried out by allowing the protein movement. The strengths of the individual scoring functions were combined to produce a consensus that is more robust and accurate than any single function for evaluating the ligand-receptor interactions. Thus, CScore (consensus score) was used for ranking the affinity of ligands bound to the active site of a receptor. CScore integrates a number of popular scor- ing functions and provides several functions: D_Score, charge and van der Waals interactions between the protein and the ligand; PMF (potential of mean force) Score; G_Score, showing hydrogen bonding, complex (ligand-protein), and internal (ligand-ligand) energies; and Chem_Score, points for hydrogen bonding, lipophilic contact, and rotational entropy, along with an intercept term. CScore was automatically computed from the six scores $(0,1,2,3,4$, and 5$)$; the best CScore is 5 .

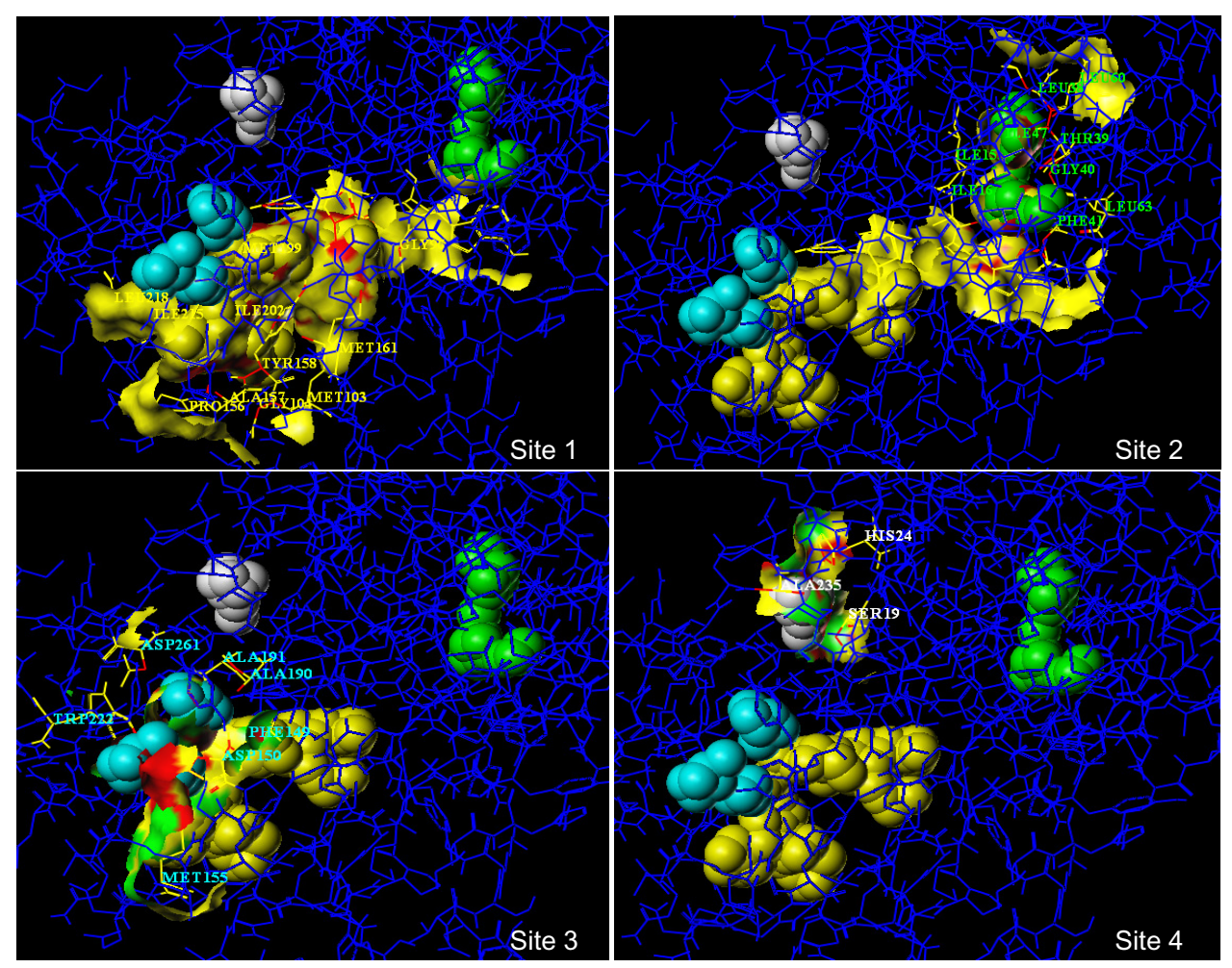

Figure 7 The possible binding-sites (spacefill models) of ENR enzyme from Mycobacterium tuberculosis; site I, yellow; site 2, green; site 3, cyan; site 4, white. 

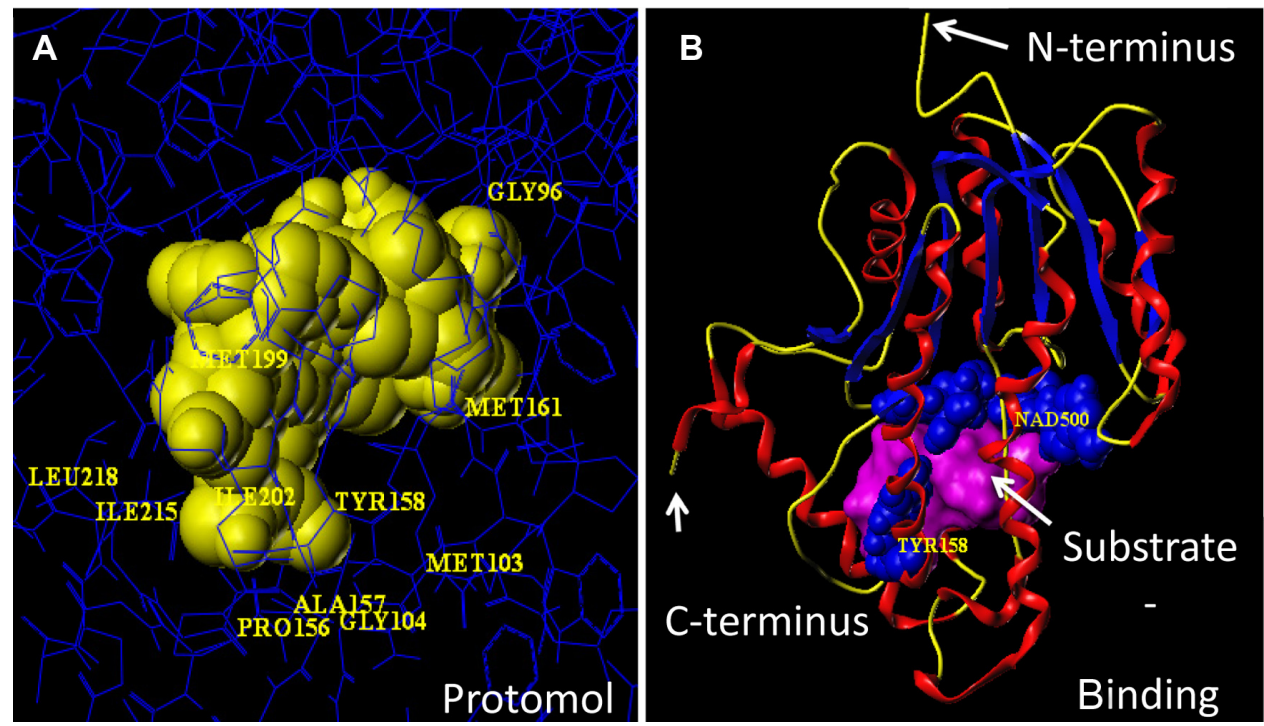

Figure 8 (A) Protomol generated (yellow-colored spacefill model) at ENR enzyme, using a ligand-based approach and (B) active site at ENR enzyme (Tyr I58 and NAD ${ }^{+}$ spacefill models in blue; magenta, Connolly surface; ribbon colored by secondary structure).

Structures with scores of 3 or 4 merit further consideration. Structures with a CScore of 0 are consistently considered bad by all scoring functions and should be dropped. Additional scores were observed as we allowed the protein movement.

\section{Surflex-Docking}

Docking simulation plays a key role in structural molecular biology and computer-assisted drug designing. Binding models for receptors and ligands via the lowest energy pathway may be best represented by docking simulations. One of the most effective docking techniques is Surflex-Dock. The literature review showed that Surflex-Dock has several advantages in drug design studies.

In our previous communication, protein flexibility was not considered, ${ }^{17}$ and hence, in the present study, we have investigated the effect of protein flexibility on the docking process. To accomplish this process, the protein movement was allowed, which means whether to allow flexibility of protein atoms whose van der Waals surface distances from ligand atoms are less than $4 \AA$ and to adapt the active site conformation to the docked ligand. Only hydrogens were allowed in protein flexibility to optimize hydroxyls and thiols,
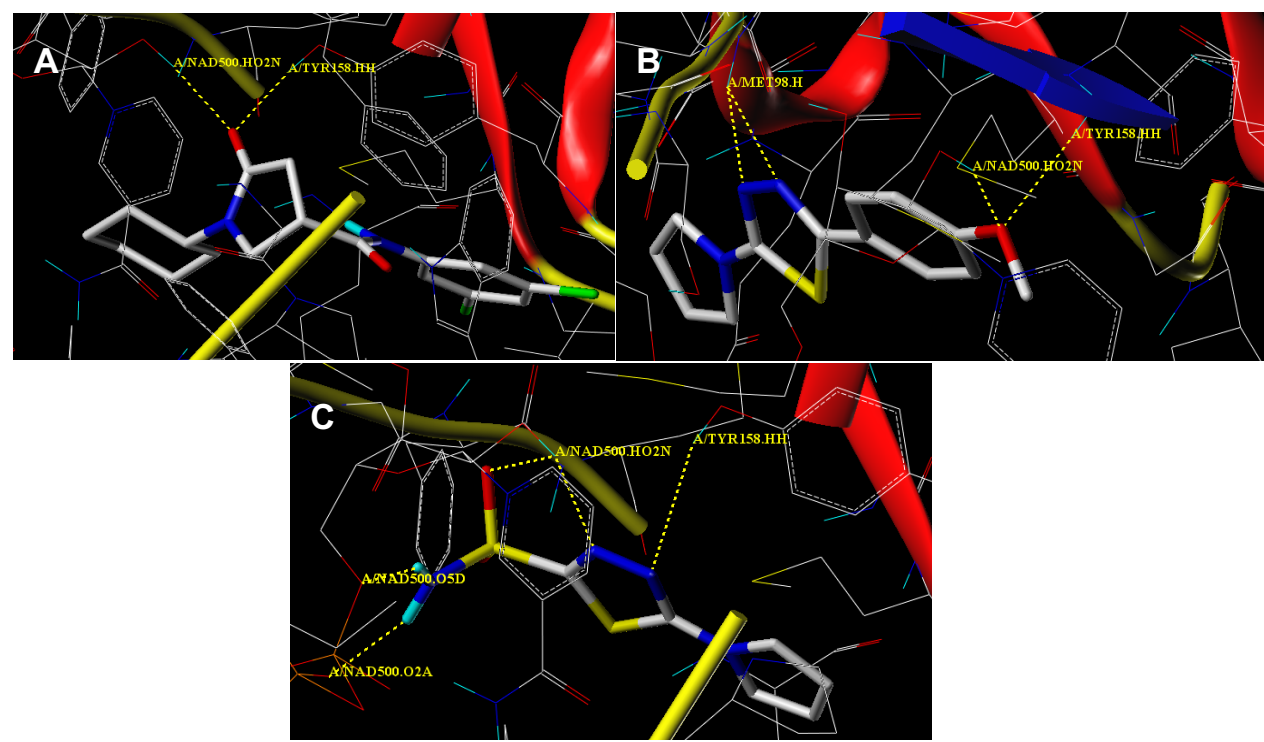

Figure 9 Docking conformation (capped sticks model in atom type color) of 64I (A), compounds $4 \mathrm{~b}$ (B), and 8a (C) at the active site (yellow dotted lines indicate H-bond); flexible docking. 
as well as all protons in the protein pocket. The binding models of 641, 4b, and 8a are depicted in Figure 9A-C. Model 641 showed two H-bonding interactions; the oxygen of the carbonyl group on pyrrolidine makes H-bonds with that of the $\mathrm{OH}$ group of the active site of Tyr158 (2.12 $\AA$ ) and NAD ${ }^{+}$ ribose ( $1.95 \AA$ ). Compound $4 \mathrm{~b}$ makes four hydrogen bonds: the oxygen atom of the methoxy group makes two H-bonds with Tyr158 (2.23 $\AA$ ) and $\mathrm{NAD}^{+}$ribose (1.82 $\AA$ ), and that of nitrogens at the third and fourth positions of the oxadiazole ring makes two H-bonds with Met98 (1.97 and 2.29 A). In the case of compound $8 \mathrm{a}$, it makes five H-bonds; that is, at the third position nitrogen (Tyr158, $2.88 \AA$ ) and the fourth position nitrogen $\left(\mathrm{NAD}^{+}\right.$ribose, $2.21 \AA$ ) of the oxadiazole ring, compound 8 a makes two $\mathrm{H}$-bonds. Free $\mathrm{NH}_{2}$ of sulphonamide group makes two $\mathrm{H}$-bonds with $\mathrm{NAD}^{+}$ribose $(2.04$ and $1.91 \AA$ ), and one more $\mathrm{H}$-bond was observed between $\mathrm{NAD}^{+}$ribose and the oxygen of $\mathrm{SO}_{2}$ with a distance of $2.42 \AA$. However, in the case of nonprotein flexibility (compounds $641,4 \mathrm{~b}$, and $8 \mathrm{a}$ ), the H-bonding interactions at the active site with their respective distances are given in Table 2 . The binding models of $641,4 \mathrm{~b}$, and $8 \mathrm{a}$ by nonprotein flexibility docking are depicted in Figures 10-12.

Furthermore, interactions were also stabilized by the hydrophobic residues of the inner cavity, such as in Ile16, Ile21, Phe97, Met98, Pro99, Met103, Pro156, Ala157,
Typ160, Met161, Pro193, and Ile194 and hydrophilic residues such as Gly14, Ser19, Ser20, Ser94, Gly96, Gln100, Gly102, Gly104, Gly119, Asp148, Asp150, Tyr158, Asn159, Thr162, Gly192, and Thr196. These amino acid residues were involved in the active cavity (shown in Figure 13A and B). Pmove score, the average movement of the protein atoms in the pocket for this pose, was observed in the range of $0.08-0.12$, but not much change was observed when it was aligned with both the models. The docking scores, namely, C-score, Crash, Polar, D_Score, PMF_Score, G_Score, and Chem_Score, from SurflexDock are given in Tables 3 and 4. None of the molecules were observed with better scores than the re-docked 641 ligand, but they are making key interactions at the active site or substrate binding site. Comparing the predicted (CScore) and experimental (pMIC) results, it can be said that compounds with pMIC values of 4.903 and 4.602 showed the highest CScores (6.36-5.45) compared with other molecules in the series.

\section{Experimental}

All chemicals used were purchased either from SigmaAldrich, Fine-Chem Limited, or Spectrochem Pvt Ltd. Solvents were of reagent grade, and whenever necessary, they were purified and dried using the standard methods.

Table 2 Key H-bonding interactions observed by simple and flexible docking processes with distance in $\AA$.

\begin{tabular}{|c|c|c|c|c|}
\hline \multicolumn{5}{|c|}{$\begin{array}{l}\text { 1-Cyclohexyl-N-(3,5-dichlorophenyl)-5-oxopyrrolidine-3-carboxamide } \\
\text { (pyrrolidine carboxamide or 641) }\end{array}$} \\
\hline & & & & \\
\hline Compound & Protein Flexibility & A & Simple (Base) & $\mathbf{A}$ \\
\hline \multirow[t]{2}{*}{641} & Pyrrolidine $\mathrm{C}=\mathrm{O}-\mathrm{NAD}^{+}$ & 1.95 & Pyrrolidine $\mathrm{C}=\mathrm{O}-\mathrm{NAD}^{+}$ & 1.91 \\
\hline & Pyrrolidine C=O-Tyr I 58 & 2.12 & Pyrrolidine $\mathrm{C}=\mathrm{O}-\mathrm{Tyr} \mathrm{I} 58$ & 2.07 \\
\hline \multirow[t]{5}{*}{$4 b$} & $\mathrm{CH}_{3} \mathrm{O}-\mathrm{Tyr} \mathrm{I} 58$ & 2.23 & $\mathrm{CH}_{3} \mathrm{O}-\mathrm{Met} 98$ & 2.04 \\
\hline & $\mathrm{CH}_{3} \mathrm{O}-\mathrm{NAD}^{+}$ & 1.82 & Oxadiazole 3rd N-Tyr I58 & 2.25 \\
\hline & Oxadiazole 3rd N-Met98 & 1.97 & Oxadiazole 3rd N-NAD ${ }^{+}$ & 2.15 \\
\hline & Oxadiazole 4th N-Met98 & 2.29 & Oxadiazole 4th N-Tyr I58 & 2.74 \\
\hline & & & Oxadiazole 4th N-NAD+ & 2.44 \\
\hline \multirow[t]{5}{*}{$8 a$} & Oxadiazole 3rd N-TyrI58 & 2.88 & $\mathrm{HNH}-\mathrm{NAD}^{+}$ & 2.53 \\
\hline & Oxadiazole 4th N-NAD ${ }^{+}$ & 2.21 & OSO-TyrI58 & 2.09 \\
\hline & $\mathrm{HNH}-\mathrm{NAD}^{+}$ & 2.04 & OSO-NAD+ & 2.22 \\
\hline & $\mathrm{HNH}-\mathrm{NAD}^{+}$ & 1.91 & & \\
\hline & OSO-NAD ${ }^{+}$ & 2.42 & & \\
\hline
\end{tabular}



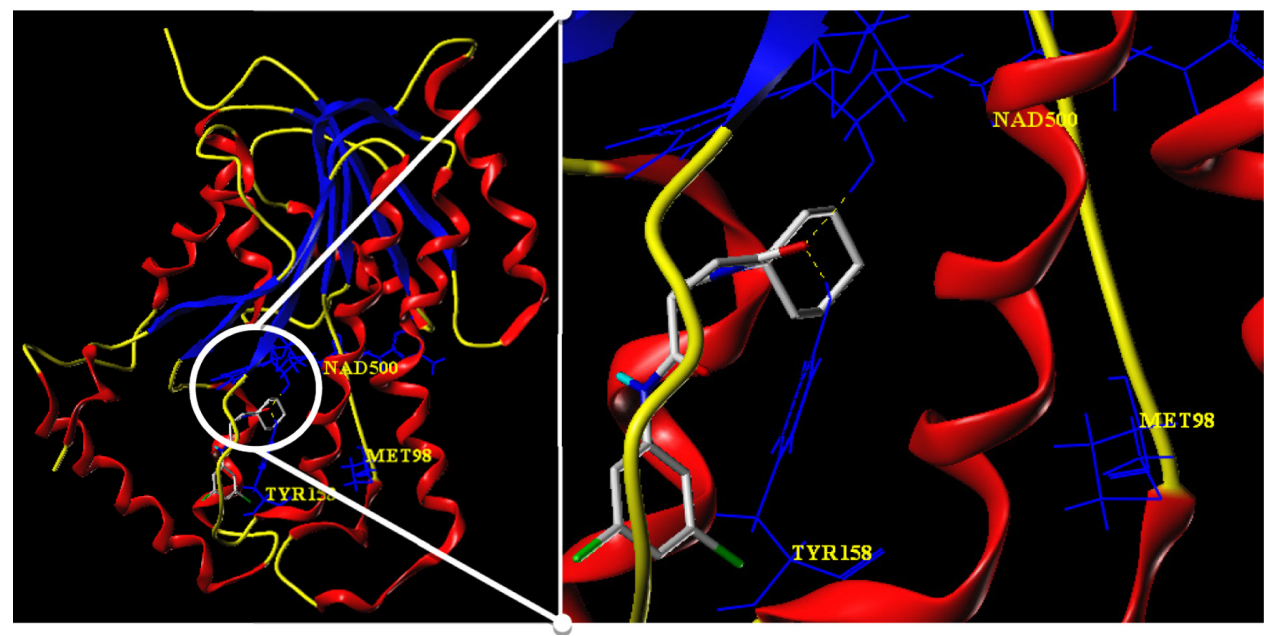

Figure 10 Docking conformation of 64 I (capped sticks model in atom type color) at the active site (yellow dotted lines indicate H-bond).

The melting points of the compounds were determined using the Shital Scientific Industries melting point apparatus and are uncorrected. FTIR spectra were recorded on a Bruker spectrophotometer, using $\mathrm{KBr}$ pellets. The ${ }^{1} \mathrm{H}$ and ${ }^{13} \mathrm{C}$ NMR spectra were recorded on a Bruker AVANCE II $400 \mathrm{MHz}$ instrument, using dimethyl sulfoxide (DMSO)- $\mathrm{d}_{6}$ solvent and TMS as the internal standard. Chemical shifts are expressed in $\delta$ values (ppm).

Mass spectra (MS) were taken in JEOL GCMATE II GC-Mass and Waters Micromass Q-Tof Micro liquid chromatography-mass spectrometers. The compounds showed spectral data consistent with their proposed. Analytical thin-layer chromatography (TLC) was performed on precoated TLC sheets of silica gel $60 \mathrm{~F}_{254}$ (Merck, Darmstadt, Germany), visualized by long- and short-wavelength ultraviolet lamps. Chromatographic purifications were performed on Merck aluminum oxide (70-230 mesh) and Merck silica gel (70-230 mesh).

\section{General procedure for the preparation of 2-amino-5-(4-substituted phenyl)- \\ I,3,4-thiadiazoles (3a-3i)}

A mixture of appropriate aromatic acid $(50 \mathrm{mmol})$, $\mathrm{N}$-aminothiourea $(50 \mathrm{mmol})$, and $\mathrm{POCl}_{3}(13 \mathrm{~mL})$ was heated at $75^{\circ} \mathrm{C}$ for 30 minutes and cooled, to which 10 $\mathrm{mL}$ of water was added, and the mixture was refluxed for 4 hours. The $\mathrm{pH}$ was then adjusted to 8.0 by adding $50 \%$ sodium hydroxide solution. The separated solid was filtered and recrystallized from ethanol to give the desired compounds. $^{32}$
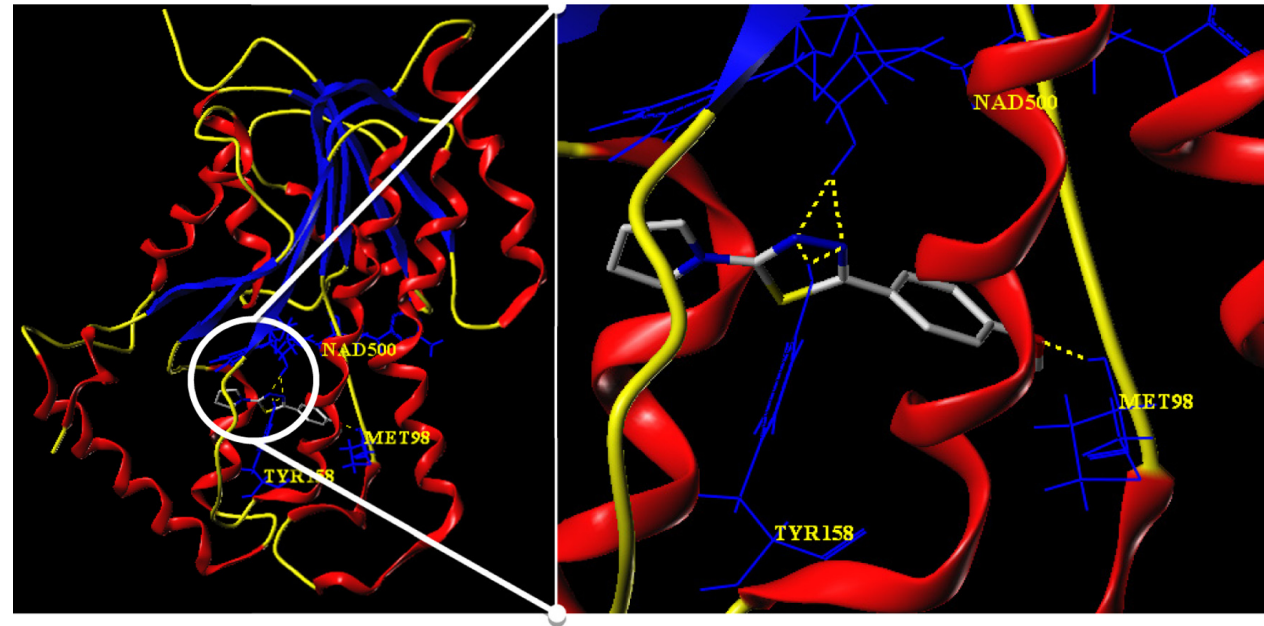

Figure I I Docking conformation of compound 4b (capped sticks model in atom type color) at the active site (yellow dotted lines indicate $\mathrm{H}$-bond). 

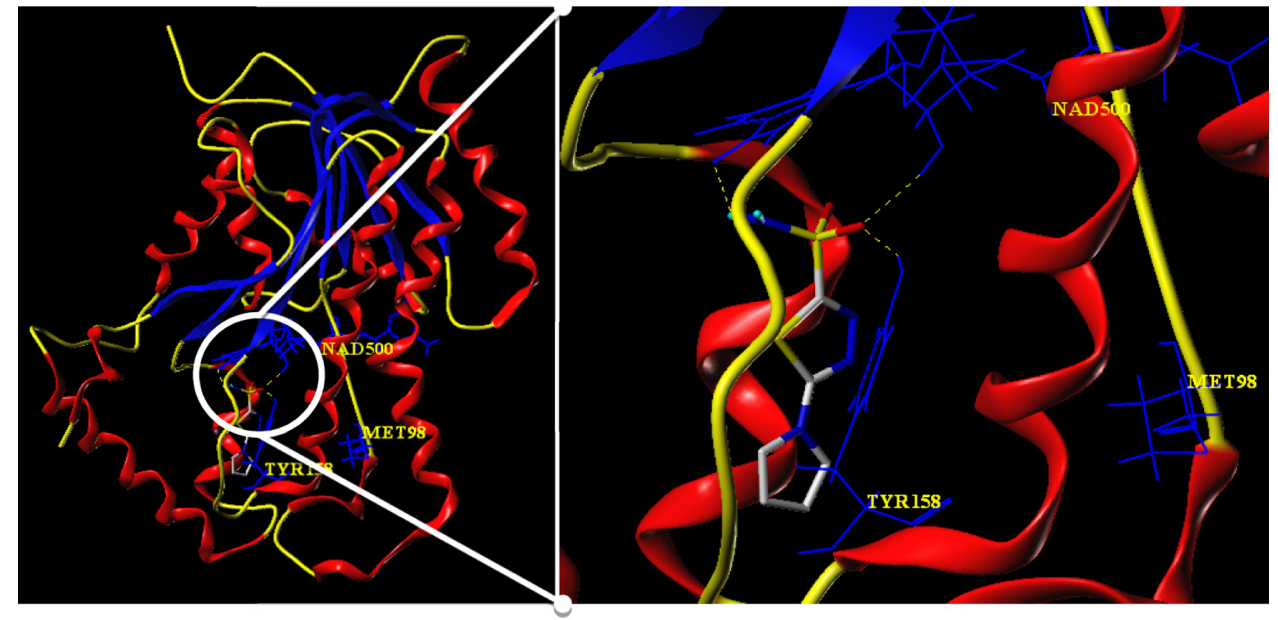

Figure 12 Docking conformation of compound 8a (capped sticks model in atom type color) at the active site (yellow dotted lines indicate H-bond).

\section{General procedure for the preparation} of 5-(4-substituted phenyl)-2-( IH-pyrrol$|-y|) ~ I-I, 3,4-$ thiadiazoles $(4 a-4 i)$

To a solution of 2-amino-5-(4-substituted phenyl)-1,3,4thiadiazoles $(10 \mathrm{mmol})$ in $20 \mathrm{~mL}$ glacial acetic acid, 2,5dimethoxytetrahydrofuran $(15 \mathrm{mmol})$ was added slowly at room temperature and refluxed for 1 hour (monitored by TLC). The reaction mixture was poured into ice-cold water and basified with sodium bicarbonate solution. The separated solid was collected, washed with water, and dried. All the compounds were recrystallized, using ethanol as the solvent.

\section{4-Phenyl-5-(IH-pyrrol-I-yl)-I,3,4- thiadiazole (4a)}

Yield, 78\%: $\mathrm{mp} 136^{\circ} \mathrm{C}-138^{\circ} \mathrm{C}$; FTIR (KBr): 2,923 and 2,848 (Ar-H), 1,509 (C=N) cm ${ }^{-1}$; ${ }^{1} \mathrm{H}$ NMR $(400 \mathrm{MHz}$, deuterated chloroform $\left.\left[\mathrm{CDCl}_{3}\right]\right) \delta$ ppm: $6.44\left(\mathrm{~s}, 2 \mathrm{H}\right.$, pyrrole- $\mathrm{C}_{3}$, and $\left.\mathrm{C}_{4}-\mathrm{H}\right), 7.55\left(\mathrm{dd}, 2 \mathrm{H}\right.$, pyrrole- $\mathrm{C}_{2}$ and $\left.\mathrm{C}_{5}-\mathrm{H}\right), 7.57-7.59$ (m, 3H, ph- $\left.\mathrm{C}_{3}, \mathrm{C}_{4}, \mathrm{C}_{5}-\mathrm{H}\right), 7.95\left(\mathrm{~d}, 2 \mathrm{H}, \mathrm{ph}_{-} \mathrm{C}_{2}\right.$, and $\left.\mathrm{C}_{6}-\mathrm{H}\right) ;{ }^{13} \mathrm{C}$ NMR (400 MHz, $\mathrm{CDCl}_{3}$ ) $\delta$ ppm: 113.54 (pyrrole- $\mathrm{C}_{3}$ and $\mathrm{C}_{4}$ ), 121.66 (pyrrole- $\mathrm{C}_{2}$ and $\mathrm{C}_{5}$ ), 127.68 ( $\mathrm{ph}^{-\mathrm{C}_{2}}$ and $\mathrm{C}_{6}$ ), 129.82 $\left(\mathrm{ph}-\mathrm{C}_{4}\right), 129.99\left(\mathrm{ph} \mathrm{C}_{3}\right.$ and $\left.\mathrm{C}_{5}\right), 131.85\left(\mathrm{ph}^{-\mathrm{C}_{1}}\right), 162.22$ (thiadiazole- $\mathrm{C}_{2}$ ), 164.24 (thiadiazole- $\mathrm{C}_{5}$ ); $\mathrm{MS}(\mathrm{EI}): \mathrm{m} / \mathrm{z}=$ found $226.97\left[\mathrm{M}^{+}\right]$; calcd. 227.05. Anal. $\mathrm{C}_{12} \mathrm{H}_{9} \mathrm{~N}_{3} \mathrm{~S}$.

\section{2-(4-Methoxyphenyl)-5-(|H-pyrrol-I-y|)- I,3,4-thiadiazole (4b)}

Yield, $71 \%$ : $\mathrm{mp} 140^{\circ} \mathrm{C}-142^{\circ} \mathrm{C}$; FTIR (KBr): 2,926 and 2,836 (Ar-H), 1,605 (C=N) cm ${ }^{-1}$; ${ }^{1} \mathrm{H}$ NMR (500 MHz, $\left.\mathrm{CDCl}_{3}\right) \delta$ ppm: 3.87 (s, $\left.3 \mathrm{H}, \mathrm{OCH}_{3}\right), 6.39$ (dd, $2 \mathrm{H}$, pyrrole- $\mathrm{C}_{3}$, and $\left.\mathrm{C}_{4}-\mathrm{H}\right)$, $7.05\left(\mathrm{dd}, 2 \mathrm{H}, \mathrm{ph}-\mathrm{C}_{3}\right.$, and $\left.\mathrm{C}_{5}-\mathrm{H}\right), 7.39\left(\mathrm{dd}, 2 \mathrm{H}\right.$, pyrrole- $\mathrm{C}_{2}$, and $\left.\mathrm{C}_{5}-\mathrm{H}\right), 7.86$ (dd, $2 \mathrm{H}$, ph- $\mathrm{C}_{2}$, and $\left.\mathrm{C}_{6}-\mathrm{H}\right) ;{ }^{13} \mathrm{C}$ NMR $(300 \mathrm{MHz}$, DMSO) $\delta$ ppm: $55.27\left(\mathrm{OCH}_{3}\right), 112.65$ (pyrrole- $\mathrm{C}_{3}$ and $\left.\mathrm{C}_{4}\right)$, 114.56 ( ph- $_{3}$ and $\mathrm{C}_{5}$ ), 120.72 (pyrrole- $\mathrm{C}_{2}$ and $\mathrm{C}_{5}$ ), 121.83 (ph- $\mathrm{C}_{1}$ ), $128.65\left(\mathrm{ph}^{-\mathrm{C}_{2}}\right.$ and $\left.\mathrm{C}_{6}\right), 160.75\left(\mathrm{ph}-\mathrm{C}_{4}\right), 161.52$ (thiadiazole- $\mathrm{C}_{2}$ ), 163.32 (thiadiazole- $\mathrm{C}_{5}$ ); MS (EI): $\mathrm{m} / \mathrm{z}=$ found $257.49\left[\mathrm{M}^{+}\right]$; calcd. 257.31. Anal. $\mathrm{C}_{13} \mathrm{H}_{11} \mathrm{~N}_{3} \mathrm{OS}$.

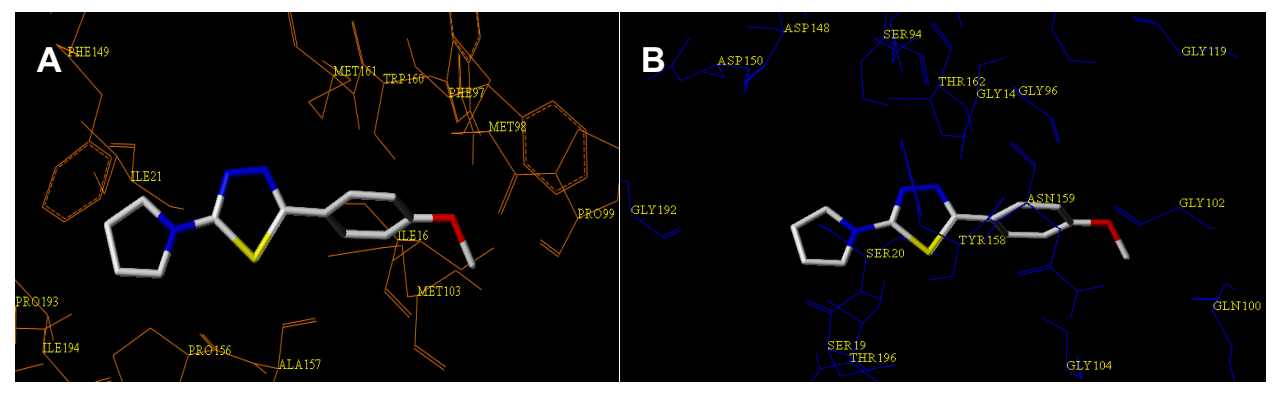

Figure 13 Hydrophobic (brown) (A) and hydrophilic (blue) (B) amino acids surrounded to compound 4b (capped sticks model in atom type color). 
Table 3 Surflex-Dock scores of pyrrolyl thiadiazole derivatives

\begin{tabular}{|c|c|c|c|c|c|c|c|c|c|c|}
\hline Compound & CScore & Crash & Polar & Strain & Total & Ligmin & Full & Complex & Cscale & Pmove \\
\hline 641 & 9.38 & -2.013 & 2.084 & 0.562 & 8.819 & 50.758 & 39.556 & 463.670 & 132.919 & 0.1004 \\
\hline $4 b$ & 6.36 & -0.393 & 2.552 & 1.105 & 4.717 & 48.173 & 42.111 & 457.829 & 128.903 & 0.1138 \\
\hline $8 a$ & 6.31 & -0.532 & 2.928 & 0.201 & 5.628 & 62.202 & 54.658 & 473.731 & 76.408 & 0.1230 \\
\hline $5 d$ & 5.85 & -0.492 & 1.439 & 0.985 & 4.607 & 56.286 & 50.581 & 471.206 & 124.398 & 0.1089 \\
\hline $8 b$ & 5.82 & -1.890 & 0.900 & 2.319 & 3.997 & 70.449 & 65.082 & 486.675 & 93.730 & 0.0825 \\
\hline $5 \mathbf{i}$ & 5.82 & -0.940 & 1.175 & 3.629 & 1.821 & 50.409 & 48.879 & 472.224 & 112.434 & 0.0946 \\
\hline $5 b$ & 5.59 & -0.581 & 1.837 & 0.914 & 4.438 & 56.254 & 50.297 & $465.65 I$ & 169.768 & 0.1158 \\
\hline $4 d$ & 5.45 & -1.039 & 2.863 & 0.894 & 3.650 & 48.203 & 43.276 & 461.266 & 102.927 & 0.0989 \\
\hline $5 f$ & 5.35 & -1.012 & 0.0002 & 6.269 & -0.952 & 53.402 & 56.588 & 486.345 & 110.978 & 0.1031 \\
\hline $5 \mathrm{~h}$ & 5.35 & -1.615 & 1.911 & 3.021 & 2.237 & 51.148 & 49.186 & 474.273 & 112.233 & 0.1100 \\
\hline $4 i$ & 5.31 & -0.697 & 1.977 & 1.046 & 4.018 & 42.317 & 37.691 & 459.429 & 91.126 & 0.1221 \\
\hline $4 f$ & 5.25 & -0.693 & 0.000 & 0.892 & 3.952 & 45.323 & 41.371 & 466.987 & 90.803 & 0.1032 \\
\hline $4 h$ & 5.09 & -1.136 & 2.025 & 1.544 & 3.221 & 43.069 & 39.179 & 462.690 & 92.538 & 0.1171 \\
\hline $5 c$ & 5.06 & -1.133 & 0.325 & 0.189 & 4.643 & 51.107 & $44.84 I$ & 467.786 & 106.628 & 0.1082 \\
\hline $4 a$ & 4.84 & $-0.77 \mid$ & 1.999 & 1.924 & 3.429 & 42.925 & 38.731 & 461.707 & 93.086 & 0.1129 \\
\hline $5 g$ & 4.83 & -1.013 & 1.166 & 2.067 & 4.297 & 51.661 & 46.173 & 469.797 & 108.415 & 0.1023 \\
\hline $4 g$ & 4.76 & -0.454 & 1.203 & 2.440 & 3.418 & 43.582 & 40.183 & 465.136 & 87.213 & 0.1121 \\
\hline $5 a$ & 4.58 & -1.254 & 0.000 & 2.975 & 2.120 & 51.004 & 48.346 & 470.792 & 108.915 & 0.1102 \\
\hline $4 e$ & 4.54 & -0.735 & 0.000 & 0.056 & 4.524 & 42.528 & 36.420 & 458.667 & 86.869 & 0.0965 \\
\hline $5 e$ & 4.33 & -1.404 & 0.000 & 0.343 & 3.987 & 50.607 & 45.235 & 467.265 & 112.289 & 0.0872 \\
\hline $4 c$ & 3.65 & -0.434 & 0.007 & 0.573 & 3.0811 & 43.028 & 39.913 & 459.516 & 99.895 & 0.1008 \\
\hline
\end{tabular}

Notes: CScore, consensus score, integrates a number of popular scoring functions for ranking the affinity of ligands bound to the active site of a receptor and reports the output of total score; Crash, the degree of inappropriate penetration by the ligand into the protein and of interpenetration (self-clash) between ligand atoms that are separated by rotatable bonds (crash scores close to 0 are favorable, negative numbers indicate penetration); Polar, contribution of the polar interactions to the total score; Pose, indication of which pose in the initial run has the best score after optimization with protein flexibility; Strain, nominal ligand strain relative to the nearby local minimum in units of pKd; Total, ligand's score corrected for strain energy; Ligmin, energy of the nearby ligand minimum (kcal/mol); Full, absolute energy of the optimized ligand, including protein interaction ( $\mathrm{kcal} / \mathrm{mol})$; Complex, absolute energy of the complex including ligand, protein pocket, and intermolecular interactions (kcal/mol); Cscale, scaled complex score that normalizes the protein score components so that ligand poses that contact different numbers of protein atoms are more directly comparable; Pmove, average movement of the protein atoms in the pocket for this pose.

\section{2-(4-Chlorophenyl)-5-(|H-pyrrol-I-yl)- I,3,4-thiadiazole (4c)}

Yield, $89 \%$ : $\mathrm{mp} 160^{\circ} \mathrm{C}-162^{\circ} \mathrm{C}$; FTIR (KBr): 2,918 and 2,848 (Ar-H), 1,584 (C=N) cm ${ }^{-1}$; ${ }^{1} \mathrm{H}$ NMR $(400 \mathrm{MHz}$, $\left.\mathrm{CDCl}_{3}\right) \delta$ ppm: $6.40\left(\mathrm{dd}, 2 \mathrm{H}\right.$, pyrrole- $\mathrm{C}_{3}$, and $\left.\mathrm{C}_{4}-\mathrm{H}\right), 7.43$ (dd, $2 \mathrm{H}$, pyrrole- $\left.\mathrm{C}_{2}, \mathrm{C}_{5}-\mathrm{H}\right), 7.56\left(\mathrm{dd}, 2 \mathrm{H}, \mathrm{ph}-\mathrm{C}_{3}, \mathrm{C}_{5}-\mathrm{H}\right)$, $7.93\left(\mathrm{dd}, 2 \mathrm{H}, \mathrm{ph}-\mathrm{C}_{2}, \mathrm{C}_{6}-\mathrm{H}\right) ;{ }^{13} \mathrm{C} \mathrm{NMR}\left(400 \mathrm{MHz}, \mathrm{CDCl}_{3}\right)$ $\delta$ ppm: 113.62 (pyrrole- $\mathrm{C}_{3}$ and $\mathrm{C}_{4}$ ), 121.69 (pyrrole- $\mathrm{C}_{2}$ and $\left.\mathrm{C}_{5}\right), 128.68$ (ph- $\mathrm{C}_{2}$ and $\left.\mathrm{C}_{6}\right), 129.36\left(\mathrm{ph} \mathrm{C}_{3}\right.$ and $\left.\mathrm{C}_{5}\right), 130.05$ $\left(\right.$ ph- $\left.\mathrm{C}_{1}\right), 136.42\left(\mathrm{ph}^{-\mathrm{C}_{4}}\right), 162.50$ (thiadiazole- $\left.\mathrm{C}_{2}\right), 163.05$ (thiadiazole- $\mathrm{C}_{5}$ ); MS (electrospray ionisation [EI]): $\mathrm{m} / \mathrm{z}=$ found $261.78\left[\mathrm{M}^{+}\right], 263.78\left[\mathrm{M}^{+}+2\right]$; calcd. 261.73. Anal. $\mathrm{C}_{12} \mathrm{H}_{8} \mathrm{ClN}_{3} \mathrm{~S}$.

\section{2-(4-Nitrophenyl)-5-(IH-pyrrol-I-yl)- I,3,4-thiadiazole (4d)}

Yield, $63 \%$ : $\mathrm{mp} 216^{\circ} \mathrm{C}-219^{\circ} \mathrm{C}$; FTIR (KBr): 2,916, 2,848 $(\mathrm{Ar}-\mathrm{H}), 1,600(\mathrm{C}=\mathrm{N}), 1,503,1,339\left(\mathrm{NO}_{2}\right) \mathrm{cm}^{-1} ;{ }^{1} \mathrm{H}$ NMR $\left(400 \mathrm{MHz}, \mathrm{CDCl}_{3}\right) \delta$ ppm: $6.44\left(\mathrm{dd}, 2 \mathrm{H}\right.$, pyrrole- $\mathrm{C}_{3}$, and $\left.\mathrm{C}_{4}-\mathrm{H}\right), 7.54\left(\mathrm{dd}, 2 \mathrm{H}\right.$, pyrrole $\mathrm{C}_{2}$, and $\left.\mathrm{C}_{5}-\mathrm{H}\right), 8.23(\mathrm{dd}, 2 \mathrm{H}$, ph- $\mathrm{C}_{2}$, and $\left.\mathrm{C}_{6}-\mathrm{H}\right), 8.41$ (dd, $2 \mathrm{H}$, ph- $\mathrm{C}_{3}$, and $\left.\mathrm{C}_{5}-\mathrm{H}\right) ;{ }^{13} \mathrm{C} \mathrm{NMR}$ $\left(400 \mathrm{MHz}, \mathrm{CDCl}_{3}\right.$ ) $\delta$ ppm: 113.27 (pyrrole- $\mathrm{C}_{3}$ and $\mathrm{C}_{4}$ ), 121.12 (pyrrole- $\mathrm{C}_{2}$ and $\mathrm{C}_{5}$ ), $124.48\left(\right.$ ph $^{-\mathrm{C}_{3}}$ and $\left.\mathrm{C}_{5}\right), 128.28$ (ph- $\mathrm{C}_{2}$ and $\left.\mathrm{C}_{6}\right), 134.99\left(\mathrm{ph}^{-\mathrm{C}_{1}}\right), 148.58\left(\mathrm{ph}^{-\mathrm{C}_{4}}\right), 161.39$ (thiadiazole- $\mathrm{C}_{2}$ ), 162.89 (thiadiazole- $\mathrm{C}_{5}$ ); MS (EI): $\mathrm{m} / \mathrm{z}=$ found $272.31\left[\mathrm{M}^{+}\right], 273.31\left[\mathrm{M}^{+}+1\right]$; calcd. 272.28. Anal. $\mathrm{C}_{12} \mathrm{H}_{8} \mathrm{~N}_{4} \mathrm{O}_{2} \mathrm{~S}$.

\section{2-(4-Bromophenyl)-5-(|H-pyrrol- I-yl)- I,3,4-thiadiazole (4e)}

Yield, 58\%: $\mathrm{mp} 162^{\circ} \mathrm{C}-165^{\circ} \mathrm{C}$; FTIR (KBr): 2,919 and 2,847 (Ar-H), 1,581 (C=N), $598(\mathrm{C}-\mathrm{Br}) \mathrm{cm}^{-1}$; ${ }^{1} \mathrm{H}$ NMR $(400 \mathrm{MHz}$, $\mathrm{CDCl}_{3}$ ) $\delta$ ppm: $6.42\left(\mathrm{dd}, 2 \mathrm{H}\right.$, pyrrole- $\mathrm{C}_{3}$, and $\left.\mathrm{C}_{4}-\mathrm{H}\right), 7.49$ (dd, $2 \mathrm{H}$, pyrrole $\mathrm{C}_{2}$, and $\left.\mathrm{C}_{5}-\mathrm{H}\right), 7.75\left(\mathrm{dd}, 2 \mathrm{H}\right.$, ph- $\mathrm{C}_{2}$, and $\left.\mathrm{C}_{6}-\mathrm{H}\right)$, 7.88 (dd, $2 \mathrm{H}, \mathrm{ph}_{-} \mathrm{C}_{3}$, and $\left.\mathrm{C}_{5}-\mathrm{H}\right) ;{ }^{13} \mathrm{C} \mathrm{NMR}\left(400 \mathrm{MHz}, \mathrm{CDCl}_{3}\right.$ ) $\delta$ ppm: 114.12 (pyrrole- $\mathrm{C}_{3}$ and $\mathrm{C}_{4}$ ), 122.02 (pyrrole- $\mathrm{C}_{2}$ and $\left.\mathrm{C}_{5}\right), 125.61\left(\mathrm{ph}^{-\mathrm{C}_{3}}\right.$ and $\left.\mathrm{C}_{5}\right), 129.15\left(\mathrm{ph}-\mathrm{C}_{2}\right.$ and $\left.\mathrm{C}_{6}\right), 141.11$ $\left(\mathrm{ph}-\mathrm{C}_{1}\right), 150.02\left(\mathrm{ph}^{-} \mathrm{C}_{4}\right), 162.77$ (thiadiazole- $\left.\mathrm{C}_{2}\right), 164.03$ (thiadiazole- $\mathrm{C}_{5}$ ); MS (EI): $\mathrm{m} / \mathrm{z}=$ found $306.09\left[\mathrm{M}^{+}\right], 308.09$ $\left[\mathrm{M}^{+}+2\right]$; calcd. 306.18. Anal. $\mathrm{C}_{12} \mathrm{H}_{8} \mathrm{BrN}_{3} \mathrm{~S}$. 
Table 4 Different energy scores for pyrrolyl thiadiazole derivatives from the Surflex-Docking

\begin{tabular}{lllll}
\hline Compound & D_Score & PMF_Score & G_Score & Chem_Score \\
\hline $\mathbf{6 4 I}$ & -165.064 & -47.432 & -307.404 & -40.847 \\
$\mathbf{4 b}$ & -94.264 & -23.652 & -160.044 & -30.804 \\
$\mathbf{8 a}$ & -82.683 & -19.103 & -144.253 & -21.664 \\
$\mathbf{5 d}$ & -110.202 & -41.217 & -205.635 & $-33.36 \mid$ \\
$\mathbf{8 b}$ & -111.536 & -29.986 & $-223.38 \mid$ & -24.604 \\
$\mathbf{5 i}$ & -107.782 & -37.474 & $-190.66 \mid$ & -28.107 \\
$\mathbf{5 b}$ & -87.341 & -5.795 & -159.397 & -23.627 \\
$\mathbf{4 d}$ & -106.140 & -35.445 & -190.190 & -30.956 \\
$\mathbf{5 f}$ & -112.667 & -49.694 & -201.966 & -31.949 \\
$\mathbf{5 h}$ & -113.189 & -37.517 & -200.604 & -30.856 \\
$\mathbf{4 i}$ & -98.115 & -62.598 & $-174.07 \mid$ & -30.076 \\
$\mathbf{4 f}$ & -107.354 & -48.404 & -206.646 & -28.704 \\
$\mathbf{4 h}$ & -102.147 & -56.944 & -171.950 & -31.937 \\
$\mathbf{5 c}$ & -118.211 & -37.568 & $-232.89 \mid$ & -34.055 \\
$\mathbf{4 a}$ & -102.014 & -55.794 & -182.947 & $-32.48 \mid$ \\
$\mathbf{5 g}$ & -114.026 & $-46.38 \mid$ & -224.167 & $-34.07 \mid$ \\
$\mathbf{4 g}$ & -104.048 & -60.144 & -201.189 & -30.929 \\
$\mathbf{5 a}$ & -112.160 & -40.039 & -226.546 & -32.848 \\
$\mathbf{4 e}$ & $-111.80 \mid$ & -42.087 & -212.967 & -31.842 \\
$\mathbf{5 e}$ & -110.293 & -33.448 & -205.215 & -30.056 \\
$\mathbf{4 c}$ & -97.889 & -31.368 & -177.013 & -28.136 \\
\hline $\mathbf{N o t e}$ & $\mathbf{D a}$ & &
\end{tabular}

Notes: D_Score, charge and van der Waals interactions between the protein and the ligand; PMF_Score, indicating the Helmholtz free energies of interactions for protein-ligand atom pairs; PMF, potential of mean force; G_Score, showing hydrogen bonding, complex (ligand-protein), and internal (ligand-ligand) energies; Chem_Score, points for hydrogen bonding, lipophilic contact, and rotational entropy, along with an intercept term.

\section{2-(4-Methylphenyl)-5-(IH-pyrrol-I-yl)- I,3,4-thiadiazole (4f)}

Yield, $83 \%$ : $\mathrm{mp} 174^{\circ} \mathrm{C}-176^{\circ} \mathrm{C}$; FTIR (KBr): 2,917, 2,863 (Ar-H), 1,593 (C=N) cm ${ }^{-1} ;{ }^{1} \mathrm{H}$ NMR (400 MHz, $\left.\mathrm{CDCl}_{3}\right) \delta$ ppm: $2.41\left(\mathrm{~s}, 3 \mathrm{H}, \mathrm{CH}_{3}\right), 6.39$ (s, $2 \mathrm{H}$, pyrrole- $\mathrm{C}_{3}$, and $\left.\mathrm{C}_{4}-\mathrm{H}\right)$, $7.34\left(\mathrm{~d}, 2 \mathrm{H}, J=4.90 \mathrm{ph}^{-\mathrm{C}_{2}}\right.$ and $\left.\mathrm{C}_{6}-\mathrm{H}\right), 7.43(\mathrm{~s}, 2 \mathrm{H}, J=4.92$ pyrrole $\mathrm{C}_{2}$ and $\left.\mathrm{C}_{5}-\mathrm{H}\right), 7.81\left(\mathrm{~d}, 2 \mathrm{H}\right.$, ph- $\mathrm{C}_{3}$, and $\left.\mathrm{C}_{5}-\mathrm{H}\right) ;{ }^{13} \mathrm{C}$ NMR (400 MHz, $\left.\mathrm{CDCl}_{3}\right) \delta$ ppm: $27.33\left(\mathrm{CH}_{3}\right), 112.36$ (pyrrole- $\mathrm{C}_{3}$ and $\mathrm{C}_{4}$ ), 120.93 (pyrrole- $\mathrm{C}_{2}$ and $\mathrm{C}_{5}$ ), 126.03 ( $\mathrm{ph}^{-\mathrm{C}_{3}}$ and $\left.\mathrm{C}_{5}\right), 128.23\left(\mathrm{ph}-\mathrm{C}_{2}\right.$ and $\left.\mathrm{C}_{6}\right), 143.12\left(\mathrm{ph}-\mathrm{C}_{1}\right), 148.56$ $\left(\mathrm{ph}^{-\mathrm{C}_{4}}\right.$ ), 161.87 (thiadiazole- $\mathrm{C}_{2}$ ), 163.35 (thiadiazole- $\mathrm{C}_{5}$ ); MS (EI): $\mathrm{m} / \mathrm{z}=$ found $241.17\left[\mathrm{M}^{+}\right]$; calcd. 241.07. Anal. $\mathrm{C}_{13} \mathrm{H}_{11} \mathrm{~N}_{3} \mathrm{~S}$.

\section{2-(4-Aminophenyl)-2-(IH-pyrrol- I-yl)-} I,3,4-thiadiazole $(4 \mathrm{~g})$

Yield, $20 \%$ : $\mathrm{mp} 180^{\circ} \mathrm{C}-182^{\circ} \mathrm{C}$; FTIR (KBr): 3,381 $\left(\mathrm{NH}_{2}\right)$, 2,923, 2,853 (Ar-H), 1,603 (C=N) cm ${ }^{-1}$; ${ }^{1} \mathrm{HNMR}(400$ $\left.\mathrm{MHz}, \mathrm{CDCl}_{3}\right) \delta$ ppm: $6.33\left(\mathrm{dd}, 2 \mathrm{H}\right.$, pyrrole- $\mathrm{C}_{3}$, and $\left.\mathrm{C}_{4}-\mathrm{H}\right)$, $6.42\left(\mathrm{~s}, 2 \mathrm{H}, \mathrm{NH}_{2}\right), 7.35\left(\mathrm{dd}, 2 \mathrm{H}\right.$, pyrrole $\mathrm{C}_{2}$, and $\left.\mathrm{C}_{5}-\mathrm{H}\right)$, 7.44-7.7.77 (m, 4H, ph- $\mathrm{C}_{2}, \mathrm{C}_{3}, \mathrm{C}_{5}$, and $\left.\mathrm{C}_{6}-\mathrm{H}\right) ;{ }^{13} \mathrm{C}$ NMR (400 $\mathrm{MHz}, \mathrm{CDCl}_{3}$ ) $\delta$ ppm: 114.13 (pyrrole- $\mathrm{C}_{3}$ and $\mathrm{C}_{4}$ ), 123.00 (pyrrole- $\mathrm{C}_{2}$ and $\mathrm{C}_{5}$ ), 126.05 ( $\mathrm{ph}-\mathrm{C}_{3}$ and $\mathrm{C}_{5}$ ), 128.66 ( $\mathrm{ph}-\mathrm{C}_{2}$ and $\left.\mathrm{C}_{6}\right), 140.59\left(\mathrm{ph}^{-\mathrm{C}_{1}}\right), 149.55\left(\mathrm{ph}^{-\mathrm{C}_{4}}\right), 162.25$ (thiadiazole- $\mathrm{C}_{2}$ ), 164.12 (thiadiazole- $\mathrm{C}_{5}$ ); $\mathrm{MS}(\mathrm{EI}): \mathrm{m} / \mathrm{z}=$ found $242.28\left[\mathrm{M}^{+}\right]$; calcd. 242.30. Anal. $\mathrm{C}_{12} \mathrm{H}_{10} \mathrm{~N}_{4} \mathrm{~S}$.

\section{2-(4-Fluorophenyl)-5-( IH-pyrrol-I-yl)- I,3,4-thiadiazole (4h)}

Yield, $62 \%$ : $\mathrm{mp} 149^{\circ} \mathrm{C}-151^{\circ} \mathrm{C}$; FTIR (KBr): 2,918 and 2,848 $(\mathrm{Ar}-\mathrm{H}), 1,594(\mathrm{C}=\mathrm{N}) \mathrm{cm}^{-1} ;{ }^{1} \mathrm{H}$ NMR $\left(400 \mathrm{MHz}, \mathrm{CDCl}_{3}\right) \delta$ ppm: 6.40 (dd, $2 \mathrm{H}$, pyrrole- $\mathrm{C}_{3}$, and $\left.\mathrm{C}_{4}-\mathrm{H}\right), 7.33$ (dd, $2 \mathrm{H}$, pyrrole- $\mathrm{C}_{2}$, and $\left.\mathrm{C}_{5}-\mathrm{H}\right), 7.44$ (dd, $2 \mathrm{H}, \mathrm{ph}-\mathrm{C}_{3}$, and $\left.\mathrm{C}_{5}-\mathrm{H}\right), 7.98$ (dd, $2 \mathrm{H}, \mathrm{ph}-\mathrm{C}_{2}$, and $\left.\mathrm{C}_{6}-\mathrm{H}\right) ;{ }^{13} \mathrm{C} \mathrm{NMR}\left(400 \mathrm{MHz}, \mathrm{CDCl}_{3}\right) \delta$ ppm: 112.79 (pyrrole- $\mathrm{C}_{3}$ and $\mathrm{C}_{4}$ ), $116.13\left(\mathrm{ph}^{-\mathrm{C}_{3}}\right.$ and $\mathrm{C}_{5}$ ), 120.69 (pyrrole- $\mathrm{C}_{2}$ and $\mathrm{C}_{5}$ ), $129.24\left(\mathrm{ph}_{-} \mathrm{C}_{2}\right.$ and $\left.\mathrm{C}_{6}\right), 129.33$ $\left(\mathrm{ph}-\mathrm{C}_{1}\right), 161.50$ (thiadiazole- $\mathrm{C}_{2}$ ), $162.26\left(\mathrm{ph}^{-\mathrm{C}_{4}}\right), 164.92$ (thiadiazole- $\mathrm{C}_{5}$ ); $\mathrm{MS}(\mathrm{EI}): \mathrm{m} / \mathrm{z}=$ found $245.37\left[\mathrm{M}^{+}\right]$; calcd. 245.28. Anal. $\mathrm{C}_{12} \mathrm{H}_{8} \mathrm{FN}_{3} \mathrm{~S}$.

\section{2-(Pyridin-3-yl)-5-(|H-pyrrol-I-yl)-I,3, 4-thiadiazole (4i)}

Yield, $61 \%$ : $\mathrm{mp} 136^{\circ} \mathrm{C}-138^{\circ} \mathrm{C}$; FTIR (KBr): 2,988 and 2,923 (Ar-H), 1,597 (C=N) cm ${ }^{-1}$; ${ }^{1} \mathrm{H}$ NMR $\left(400 \mathrm{MHz}, \mathrm{CDCl}_{3}\right) \delta$ ppm: $6.42\left(\mathrm{dd}, 2 \mathrm{H}\right.$, pyrrole- $\mathrm{C}_{3}$, and $\left.\mathrm{C}_{4}-\mathrm{H}\right), 7.35(\mathrm{dd}, 2 \mathrm{H}$, pyrrole- $\mathrm{C}_{2}$, and $\left.\mathrm{C}_{5}-\mathrm{H}\right), 7.56-9.01\left(\mathrm{~m}, 4 \mathrm{H}\right.$, pyridine- $\mathrm{C}_{2}, \mathrm{C}_{4}-\mathrm{H}$, $\mathrm{C}_{5}-\mathrm{H}$, and $\left.\mathrm{C}_{6}-\mathrm{H}\right) ;{ }^{13} \mathrm{C} \mathrm{NMR}\left(400 \mathrm{MHz}, \mathrm{CDCl}_{3}\right.$ ) $\delta$ ppm: 109.05 (pyrrole- $\mathrm{C}_{3}$ and $\mathrm{C}_{4}$ ), 124.26 (pyridine- $\mathrm{C}_{5}$ ), 130.02 (pyrrole- $\mathrm{C}_{2}$ and $\mathrm{C}_{5}$ ), 133.54 (pyridine- $\mathrm{C}_{3}$ ), 134.06 (pyridine- $\mathrm{C}_{4}$ ), 148.23 (pyridine- $\mathrm{C}_{6}$ ), 149.08 (pyridine- $\mathrm{C}_{2}$ ), 163.39 (thiadiazole- $\mathrm{C}_{2}$ ), 174.57 (thiadiazole- $\mathrm{C}_{5}$ ); $\mathrm{MS}(\mathrm{EI}): \mathrm{m} / \mathrm{z}=$ found $228.11\left[\mathrm{M}^{+}\right]$; calcd. 228.05. Anal. $\mathrm{C}_{11} \mathrm{H}_{8} \mathrm{~N}_{4} \mathrm{~S}$.

\section{General procedure for the preparation of 5-(4-substituted phenyl)-2-(2,5-dimethyl- I H-pyrrol- I-yl)-I,3,4-thiadiazoles (5a-5i)}

To a solution of 2-amino-4-(4-substituted phenyl) thiadiazoles $(10 \mathrm{mmol})$ in $20 \mathrm{~mL}$ glacial acetic acid, acetonyl acetone (15 $\mathrm{mmol}$ ) was added slowly at room temperature and refluxed for 1 hour (monitored by TLC). This mixture was poured into ice-cold water and basified with sodium bicarbonate solution. The separated solid was collected, washed with water, dried, and recrystallized, using n-hexane as the solvent.

\section{2-(2,5-Dimethyl- I H-pyrrol- I-yl)-5-phenyl- I,3,4-thiadiazole (5a)}

Yield, 58\%: $\mathrm{mp} 234^{\circ} \mathrm{C}-238^{\circ} \mathrm{C}$; FTIR (KBr): 2,951 and 2,853 (Ar-H), 1,624 (C=N) cm ${ }^{-1}$; $\left.1 \mathrm{H} \mathrm{NMR} \mathrm{(400} \mathrm{MHz,} \mathrm{CDCl}_{3}\right) \delta$ ppm: $2.28\left(\mathrm{~s}, 6 \mathrm{H}, 2 \mathrm{CH}_{3}\right), 5.94\left(\mathrm{~s}, 2 \mathrm{H}\right.$, pyrrole- $\mathrm{C}_{3}$ and $\left.\mathrm{C}_{4}-\mathrm{H}\right)$, 
7.37-7.44 (m, 3H, ph- $\mathrm{C}_{3}, \mathrm{C}_{4}$ and $\left.\mathrm{C}_{5}-\mathrm{H}\right), 7.74-7.77(\mathrm{~m}, 2 \mathrm{H}$, ph- $\mathrm{C}_{2}$ and $\left.\mathrm{C}_{6}-\mathrm{H}\right) ;{ }^{13} \mathrm{C} \mathrm{NMR}\left(400 \mathrm{MHz}, \mathrm{CDCl}_{3}\right) \delta$ ppm: 13.01 $\left(2 \mathrm{CH}_{3}\right), 111.24$ (pyrrole- $\mathrm{C}_{3}$ and $\mathrm{C}_{4}$ ), 128.21 (pyrrole- $\mathrm{C}_{2}$ and $\mathrm{C}_{5}$ ), 129.57 (ph- $\mathrm{C}_{2}$ and $\left.\mathrm{C}_{6}\right), 132.08\left(\mathrm{ph}-\mathrm{C}_{3}\right.$ and $\left.\mathrm{C}_{5}\right), 132.90$ (ph- $\left.\mathrm{C}_{1}\right), 135.29\left(\mathrm{ph}_{4} \mathrm{C}_{4}\right), 162.06$ (thiadiazole- $\left.\mathrm{C}_{2}\right), 164.03$ (thiadiazole- $\mathrm{C}_{5}$ ); MS (EI): $\mathrm{m} / \mathrm{z}=$ found $255.01\left[\mathrm{M}^{+}\right]$; calcd. 255.08. Anal. $\mathrm{C}_{14} \mathrm{H}_{13} \mathrm{~N}_{3} \mathrm{~S}$.

\section{2-(4-Methoxyphenyl)-5-(2,5-dimethyl- $\mathrm{IH}$ - pyrrol- I-yl)- I,3,4-thiadiazole (5b)}

Yield, 38\%: $\mathrm{mp} 110^{\circ} \mathrm{C}-112^{\circ} \mathrm{C}$; FTIR (KBr): 2,922 and 2,845 (Ar-H), 1,606 (C=N) cm ${ }^{-1}$; ${ }^{1} \mathrm{H}$ NMR (400 MHz, $\left.\mathrm{CDCl}_{3}\right) \delta$ ppm: 2.24 (s, 6H, 2CH $), 3.88\left(\mathrm{~s}, 3 \mathrm{H}, \mathrm{OCH}_{3}\right), 5.92(\mathrm{~s}, 2 \mathrm{H}$, pyrrole- $\mathrm{C}_{3}$ and $\left.\mathrm{C}_{4}-\mathrm{H}\right), 7.10\left(\mathrm{dd}, 2 \mathrm{H}, \mathrm{ph}_{-} \mathrm{C}_{3}\right.$ and $\left.\mathrm{C}_{5}-\mathrm{H}\right), 7.94(\mathrm{dd}$, $2 \mathrm{H}$, ph- $\mathrm{C}_{2}$ and $\left.\mathrm{C}_{6}-\mathrm{H}\right) ;{ }^{13} \mathrm{C} \mathrm{NMR}\left(400 \mathrm{MHz}, \mathrm{CDCl}_{3}\right) \delta \mathrm{ppm}$ : $12.90\left(2 \mathrm{CH}_{3}\right), 55.26\left(\mathrm{OCH}_{3}\right), 108.60\left(\right.$ pyrrole- $\mathrm{C}_{3}$ and $\left.\mathrm{C}_{4}\right)$, 114.54 (ph- $\mathrm{C}_{3}$ and $\mathrm{C}_{5}$ ), 121.93 (pyrrole- $\mathrm{C}_{2}$ and $\mathrm{C} 5$ ), 129.28 $\left(\right.$ ph- $\mathrm{C}_{2}$ and $\left.\mathrm{C}_{6}\right), 128.92\left(\mathrm{ph}-\mathrm{C}_{1}\right), 158.52\left(\mathrm{ph}-\mathrm{C}_{4}\right), 161.79$ (thiadiazole- $\mathrm{C}_{2}$ ), 168.17 (thiadiazole- $\mathrm{C}_{5}$ ); $\mathrm{MS}(\mathrm{EI}): \mathrm{m} / \mathrm{z}=$ found 285.11 [M+]; calcd. 285.09. Anal. $\mathrm{C}_{15} \mathrm{H}_{15} \mathrm{~N}_{3} \mathrm{OS}$.

\section{2-(4-Chlorophenyl)-5-(2,5-dimethyl-I H- pyrrol-I-yl)-I,3,4-thiadiazole (5c)}

Yield, $42 \%$ : $\mathrm{mp} 128^{\circ} \mathrm{C}-130^{\circ} \mathrm{C}$; FTIR (KBr): 2,917 and 2,852 (Ar-H), 1,590 (C=N) cm ${ }^{-1}$; ${ }^{1} \mathrm{H}$ NMR $(400 \mathrm{MHz}$, $\left.\mathrm{CDCl}_{3}\right) \delta$ ppm: $2.25\left(\mathrm{~s}, 6 \mathrm{H}, 2 \mathrm{CH}_{3}\right), 5.94\left(\mathrm{~s}, 2 \mathrm{H}\right.$, pyrrole- $\mathrm{C}_{3}$ and $\left.\mathrm{C}_{4}-\mathrm{H}\right), 7.60\left(\mathrm{dd}, 2 \mathrm{H}, \mathrm{ph}-\mathrm{C}_{3}\right.$ and $\left.\mathrm{C}_{5}-\mathrm{H}\right), 8.02(\mathrm{dd}, 2 \mathrm{H}$, ph- $\mathrm{C}_{2}$ and $\left.\mathrm{C}_{6 .} \mathrm{H}\right) ;{ }^{13} \mathrm{C} \mathrm{NMR}\left(400 \mathrm{MHz}, \mathrm{CDCl}_{3}\right) \delta$ ppm: 13.00 $\left(2 \mathrm{CH}_{3}\right), 108.90$ (pyrrole- $\mathrm{C}_{3}$ and $\mathrm{C}_{4}$ ), 128.16 (pyrrole- $\mathrm{C}_{2}$ and $\left.\mathrm{C}_{5}\right), 128.85\left(\mathrm{ph}^{-\mathrm{C}_{2}}\right.$ and $\left.\mathrm{C}_{6}\right), 129.34\left(\mathrm{ph}_{-} \mathrm{C}_{3}\right.$ and $\left.\mathrm{C}_{5}\right), 129.38$ $\left(\mathrm{ph}^{-\mathrm{C}_{1}}\right), 136.50\left(\mathrm{ph}^{-\mathrm{C}_{4}}\right), 159.67$ (thiadiazole- $\left.\mathrm{C}_{2}\right), 166.99$ (thiadiazole- $\mathrm{C}_{5}$ ); MS (EI): $\mathrm{m} / \mathrm{z}$ = found $289.05\left[\mathrm{M}^{+}\right], 291.05$ $\left[\mathrm{M}^{+}+2\right]$; calcd. 289.04. Anal. $\mathrm{C}_{14} \mathrm{H}_{12} \mathrm{ClN}_{3} \mathrm{~S}$.

\section{2-(4-Nitrophenyl)-5-(2,5-dimethyl- IH- pyrrol-I-yl)-I,3,4-thiadiazole (5d)}

Yield, $43 \%$ : $\mathrm{mp} 150^{\circ} \mathrm{C}-152^{\circ} \mathrm{C}$; FTIR (KBr): 2,921 and 2,854 (Ar-H), 1,596 (C=N), 1,497, 1,331 $\left(\mathrm{NO}_{2}\right) \mathrm{cm}^{-1} ;{ }^{1} \mathrm{H}$ NMR (500 MHz, $\left.\mathrm{CDCl}_{3}\right) \delta$ ppm: $2.30\left(\mathrm{~s}, 6 \mathrm{H}, 2 \mathrm{CH}_{3}\right), 5.96$ (s, $2 \mathrm{H}$, pyrrole- $\mathrm{C}_{3}$ and $\left.\mathrm{C}_{4}-\mathrm{H}\right), 8.28\left(\mathrm{~d}, 2 \mathrm{H}, J=8.5 \mathrm{~Hz}, \mathrm{ph}_{-} \mathrm{C}_{2}\right.$ and $\left.\mathrm{C}_{6-} \mathrm{H}\right), 8.42\left(\mathrm{~d}, 2 \mathrm{H}, J=9 \mathrm{~Hz}, \mathrm{ph}-\mathrm{C}_{3}\right.$ and $\left.\mathrm{C}_{5}-\mathrm{H}\right) ;{ }^{13} \mathrm{C} \mathrm{NMR}$ $\left(400 \mathrm{MHz}, \mathrm{CDCl}_{3}\right) \delta$ ppm: $12.97\left(2 \mathrm{CH}_{3}\right), 110.12$ (pyrrole- $\mathrm{C}_{3}$ and $\mathrm{C}_{4}$ ), 127.59 (pyrrole- $\mathrm{C}_{2}$ and $\mathrm{C}_{5}$ ), 129.03 ( ph- $_{2}$ and $\mathrm{C}_{6}$ ), $131.06\left(\mathrm{ph}-\mathrm{C}_{3}\right.$ and $\left.\mathrm{C}_{5}\right), 132.87\left(\mathrm{ph}-\mathrm{C}_{1}\right), 137.57\left(\mathrm{ph}-\mathrm{C}_{4}\right)$, 161.13 (thiadiazole- $\mathrm{C}_{2}$ ), 164.25 (thiadiazole- $\mathrm{C}_{5}$ ); MS (EI): $\mathrm{m} / \mathrm{z}=$ found $300.23\left[\mathrm{M}^{+}\right], 301.23\left[\mathrm{M}^{+}+1\right]$; calcd. 300.07 Anal. $\mathrm{C}_{14} \mathrm{H}_{12} \mathrm{~N}_{4} \mathrm{O}_{2} \mathrm{~S}$.

\section{2-(4-Bromophenyl)-5-(2,5-dimethyl-I H- pyrrol- I-yl)-I,3,4-thiadiazole (5e)}

Yield, $44 \%$ : $\mathrm{mp} 108^{\circ} \mathrm{C}-110^{\circ} \mathrm{C}$; FTIR (KBr): 2,917 and 2,854 (Ar-H), 1,585 (C=N) cm ${ }^{-1} ;{ }^{1} \mathrm{H}$ NMR (400 MHz, DMSO-d $\left.{ }_{6}\right) \delta$ ppm: 2.25 (s, $\left.6 \mathrm{H}, 2 \mathrm{CH}_{3}\right), 5.94\left(\mathrm{~s}, 2 \mathrm{H}\right.$, pyrrole- $\mathrm{C}_{3}$ and $\left.\mathrm{C}_{4}-\mathrm{H}\right)$, $7.95\left(\mathrm{~d}, 2 \mathrm{H}, J=5.35 \mathrm{~Hz}\right.$, ph- $\mathrm{C}_{3}$ and $\left.\mathrm{C}_{5}-\mathrm{H}\right), 8.07$ (d, 2H, $J=$ $5.33 \mathrm{~Hz}$, ph- $\mathrm{C}_{2}$ and $\left.\mathrm{C}_{6-} \mathrm{H}\right) ;{ }^{13} \mathrm{C}$ NMR (400 MHz, DMSO- $d_{6}$ ) $\delta$ ppm: $13.01\left(2 \mathrm{CH}_{3}\right), 109.03$ (pyrrole- $\mathrm{C}_{3}$ and $\left.\mathrm{C}_{4}\right), 129.22$ (pyrrole- $\mathrm{C}_{2}$ and $\mathrm{C}_{5}$ ), 129.30 (ph- $\mathrm{C}_{2}$ and $\mathrm{C}_{6}$ ), 130.05 ( ph- $_{3}$ and $\left.\mathrm{C}_{5}\right), 133.26\left(\mathrm{ph} \mathrm{C}_{1}\right), 138.54\left(\mathrm{ph}-\mathrm{C}_{4}\right), 160.23$ (thiadiazole- $\mathrm{C}_{2}$ ), 165.15 (thiadiazole- $\mathrm{C}_{5}$ ); $\mathrm{MS}(\mathrm{EI}): \mathrm{m} / \mathrm{z}=$ found $332.56\left[\mathrm{M}^{+}\right]$, 334.56 [M+ +2$]$; calcd. 332.99. Anal. $\mathrm{C}_{14} \mathrm{H}_{12} \mathrm{BrN}_{3} \mathrm{~S}$.

\section{2-(4-Methylphenyl)-5-(2,5-dimethyl- IH- pyrrol- I-yl)-I,3,4-thiadiazole (5f)}

Yield, 53\%: $\mathrm{mp} 92^{\circ} \mathrm{C}-94^{\circ} \mathrm{C}$; FTIR (KBr): 2,921 and 2,857 (Ar-H), 1,603 (C=N) cm ${ }^{-1} ;{ }^{1} \mathrm{H}$ NMR $\left(400 \mathrm{MHz}, \mathrm{CDCl}_{3}\right) \delta$ ppm: 2.24 (s, 6H, 2CH $), 2.42\left(\mathrm{~s}, 3 \mathrm{H}, \mathrm{CH}_{3}\right), 5.93(\mathrm{~s}, 2 \mathrm{H}$, pyrrole- $\mathrm{C}_{3}$ and $\left.\mathrm{C}_{4}-\mathrm{H}\right), 7.37\left(\mathrm{~d}, 2 \mathrm{H}, J=5.05 \mathrm{ph}^{-\mathrm{C}_{3}}\right.$ and $\left.\mathrm{C}_{5}-\mathrm{H}\right)$, $7.88\left(\mathrm{~d}, 2 \mathrm{H}, J=5.10 \mathrm{ph}-\mathrm{C}_{2}\right.$ and $\left.\mathrm{C}_{6}-\mathrm{H}\right) ;{ }^{13} \mathrm{C}$ NMR $(400 \mathrm{MHz}$, $\left.\mathrm{CDCl}_{3}\right) \delta$ ppm: $13.33\left(2 \mathrm{CH}_{3}\right), 25.02\left(\mathrm{CH}_{3}\right), 110.06$ (pyrrole- $\mathrm{C}_{3}$ and $\mathrm{C}_{4}$ ), 128.59 (pyrrole- $\mathrm{C}_{2}$ and $\mathrm{C}_{5}$ ), 129.17 (ph- $\mathrm{C}_{2}$ and $\mathrm{C}_{6}$ ), $131.00\left(\mathrm{ph}-\mathrm{C}_{3}\right.$ and $\left.\mathrm{C}_{5}\right), 133.22\left(\mathrm{ph}-\mathrm{C}_{1}\right), 136.52\left(\mathrm{ph}-\mathrm{C}_{4}\right)$, 159.69 (thiadiazole- $\mathrm{C}_{2}$ ), 163.29 (thiadiazole- $\mathrm{C}_{5}$ ); MS (EI): $\mathrm{m} / \mathrm{z}=$ found $269.03\left[\mathrm{M}^{+}\right]$; calcd. 269.10. Anal. $\mathrm{C}_{15} \mathrm{H}_{15} \mathrm{~N}_{3} \mathrm{~S}$.

\section{2-(4-Aminophenyl)-2-(2,5-dimethyl- IH- pyrrol- I-yl)-I,3,4-thiadiazole (5g)}

Yield, $21 \%$ : $\mathrm{mp} 196^{\circ} \mathrm{C}-198^{\circ} \mathrm{C}$; FTIR (KBr): $3,244\left(\mathrm{NH}_{2}\right)$, 2,922 and 2,853 (Ar-H), 1,652 (C=N) cm ${ }^{-1}$; ${ }^{1} \mathrm{H}$ NMR (400 $\left.\mathrm{MHz}, \mathrm{CDCl}_{3}\right) \delta$ ppm: $2.06\left(\mathrm{~s}, 6 \mathrm{H}, 2 \mathrm{CH}_{3}\right), 5.85(\mathrm{~s}, 2 \mathrm{H}$, pyrrole- $\mathrm{C}_{3}$ and $\left.\mathrm{C}_{4}-\mathrm{H}\right), 7.38\left(\mathrm{~s}, 2 \mathrm{H}, \mathrm{NH}_{2}\right), 7.98-8.15(\mathrm{~m}, 4 \mathrm{H}$, ph- $\mathrm{C}_{2}, \mathrm{C}_{3}, \mathrm{C}_{5}$ and $\left.\mathrm{C}_{6}-\mathrm{H}\right) ;{ }^{13} \mathrm{C} \mathrm{NMR}\left(400 \mathrm{MHz}, \mathrm{CDCl}_{3}\right) \delta$ ppm: $13.22\left(2 \mathrm{CH}_{3}\right), 108.69$ (pyrrole- $\mathrm{C}_{3}$ and $\left.\mathrm{C}_{4}\right), 127.53$ (pyrrole- $\mathrm{C}_{2}$ and $\left.\mathrm{C}_{5}\right), 129.36$ (ph- $\mathrm{C}_{2}$ and $\left.\mathrm{C}_{6}\right), 130.59\left(\mathrm{ph}^{-\mathrm{C}_{3}}\right.$ and $\left.\mathrm{C}_{5}\right), 132.05$ (ph- $\mathrm{C}_{1}$ ), $138.42\left(\mathrm{ph}^{-\mathrm{C}_{4}}\right), 161.00$ (thiadiazole- $\left.\mathrm{C}_{2}\right), 164.67$

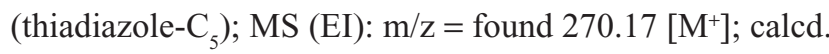
270.09. Anal. $\mathrm{C}_{14} \mathrm{H}_{14} \mathrm{~N}_{4} \mathrm{~S}$.

\section{2-(4-Fluorophenyl)-5-(2,5-dimethyl- IH- pyrrol- I-yl)-I,3,4-thiadiazole (5h)}

Yield, $41 \%$ : $\mathrm{mp} 118^{\circ} \mathrm{C}-120^{\circ} \mathrm{C}$; FTIR (KBr): 2,920 and 2,852 (Ar-H), 1,612 (C=N) cm ${ }^{-1} ;{ }^{1} \mathrm{H}$ NMR (400 MHz, $\left.\mathrm{CDCl}_{3}\right) \delta$ ppm: $2.25\left(\mathrm{~s}, 6 \mathrm{H}, 2 \mathrm{CH}_{3}\right), 5.94\left(\mathrm{~s}, 2 \mathrm{H}\right.$, pyrrole- $\mathrm{C}_{3}$ and $\left.\mathrm{C}_{4}-\mathrm{H}\right)$, 7.30-8.07 (m, 4H, ph- $\mathrm{C}_{2}, \mathrm{C}_{3}, \mathrm{C}_{5}$ and $\left.\mathrm{C}_{6}-\mathrm{H}\right) ;{ }^{13} \mathrm{C}$ NMR (400 $\left.\mathrm{MHz}, \mathrm{CDCl}_{3}\right) \delta$ ppm: $12.97\left(2 \mathrm{CH}_{3}\right), 105.83$ (pyrrole- $\mathrm{C}_{3}$ and $\mathrm{C}_{4}$ ), 116.37 (ph- $\mathrm{C}_{3}$ and $\mathrm{C}_{5}$ ), 129.33 (pyrrole- $\mathrm{C}_{2}$ and 


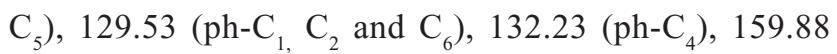
(thiadiazole- $\mathrm{C}_{2}$ ), 163.05 (thiadiazole- $\mathrm{C}_{5}$ ); $\mathrm{MS}(\mathrm{EI}): \mathrm{m} / \mathrm{z}=$ found $273.01\left[\mathrm{M}^{+}\right]$; calcd. 273.07. Anal. $\mathrm{C}_{14} \mathrm{H}_{12} \mathrm{FN}_{3} \mathrm{~S}$.

\section{2-(2,5-Dimethyl- I H-pyrrol- I-yl)-5- (pyridin-3-yl)-I,3,4-thiadiazole (5i)}

Yield, $39 \%$ : $\mathrm{mp} 103^{\circ} \mathrm{C}-105^{\circ} \mathrm{C}$; FTIR (KBr): 2,918 and 2,855 (Ar-H), 1,602 (C=N) cm ${ }^{-1} ;{ }^{1} \mathrm{H}$ NMR (400 MHz, $\left.\mathrm{CDCl}_{3}\right) \delta$ ppm: $2.26\left(\mathrm{~s}, 6 \mathrm{H}, 2 \mathrm{CH}_{3}\right), 5.83\left(\mathrm{~s}, 2 \mathrm{H}\right.$, pyrrole- $\mathrm{C}_{3}$ and $\left.\mathrm{C}_{4}-\mathrm{H}\right), 7.42-8.77\left(\mathrm{~m}, 4 \mathrm{H}\right.$, pyridine- $\mathrm{C}_{2}, \mathrm{C}_{4}, \mathrm{C}_{5}$ and $\left.\mathrm{C}_{6}-\mathrm{H}\right)$; ${ }^{13} \mathrm{C}$ NMR (400 MHz, $\left.\mathrm{CDCl}_{3}\right) \delta$ ppm: $12.89\left(2 \mathrm{CH}_{3}\right), 105.73$ (pyrrole- $\mathrm{C}_{3}$ and $\mathrm{C}_{4}$ ), 123.16 (pyridine- $\mathrm{C}_{5}$ ), 129.31 (pyrrole- $\mathrm{C}_{2}$ and $\mathrm{C}_{5}$ ), 131.24 (pyridine- $\mathrm{C}_{3}$ ), 133.57 (pyridine- $\mathrm{C}_{4}$ ), 148.03 (pyridine- $\mathrm{C}_{6}$ ), 148.99 (pyridine- $\mathrm{C}_{2}$ ), 163.22 (thiadiazole- $\mathrm{C}_{2}$ ), 174.03 (thiadiazole- $\mathrm{C}_{5}$ ); MS (EI): $\mathrm{m} / \mathrm{z}=$ found $256.13\left[\mathrm{M}^{+}\right]$; calcd. 256.08. Anal. $\mathrm{C}_{13} \mathrm{H}_{12} \mathrm{~N}_{4} \mathrm{~S}$.

\section{Synthesis of 2-(IH-pyrrol- I-yl)-5- sulfonamido-I,3,4-thiadiazole (8a)}

To a solution of 2-amino-5-sulfonamido-1,3,4-thiadiazole (10 $\mathrm{mmol})$ in $20 \mathrm{~mL}$ glacial acetic acid, 2,5dimethoxytetrahydrofuran $(15 \mathrm{mmol})$ was added slowly at room temperature and was refluxed for 1 hour (monitored by TLC). The reaction mixture was poured into ice-cold water and basified with sodium bicarbonate solution. The separated solid was collected, washed with water, dried, and recrystallized from aqueous ethanol.

Yield, $40 \%$ : $\mathrm{mp} 188^{\circ} \mathrm{C}-190^{\circ} \mathrm{C}$; FTIR (KBr): $3,358.53$, 3,253.98 $\left(\mathrm{SO}_{2} \mathrm{NH}_{2}\right), 3,108.56(\mathrm{Ar}-\mathrm{H}), 1,514.81(\mathrm{C}=\mathrm{N})$, $1,347.45\left(\mathrm{SO}_{2}{ }^{\text {as}}\right), 1,174.42\left(\mathrm{SO}_{2}{ }^{\text {sym }}\right) \mathrm{cm}^{-1} ;{ }^{1} \mathrm{H}$ NMR $(400$ $\left.\mathrm{MHz}, \mathrm{CDCl}_{3}\right) \delta$ ppm: $6.46\left(\mathrm{~s}, 2 \mathrm{H}\right.$, pyrrole- $\mathrm{C}_{3}$ and $\left.\mathrm{C}_{4}-\mathrm{H}\right)$, $7.61\left(\mathrm{~s}, 2 \mathrm{H}\right.$, pyrrole- $\left.\mathrm{C}_{2}, \mathrm{C}_{5}-\mathrm{H}\right), 8.59\left(\mathrm{~s}, 2 \mathrm{H}, \mathrm{NH}_{2}\right) ;{ }^{13} \mathrm{C}$ NMR $\left(400 \mathrm{MHz}, \mathrm{CDCl}_{3}\right) \delta$ ppm: 114.21 (pyrrole- $\mathrm{C}_{3}$ and $\mathrm{C}_{4}$ ), 122.13 (pyrrole- $\mathrm{C}_{2}$ and $\mathrm{C}_{5}$ ), 165.29 (thiadiazole- $\mathrm{C}_{2}$ ), 166.32 (thiadiazole- $\mathrm{C}_{5}$ ); MS (EI): $\mathrm{m} / \mathrm{z}$ = found $229.07\left[\mathrm{M}^{+}\right]$; calcd. 229.99. Anal. $\mathrm{C}_{6} \mathrm{H}_{6} \mathrm{~N}_{4} \mathrm{O}_{2} \mathrm{~S}_{2}$.

\section{Synthesis of 2-(2,5-dimethyl- I H-pyrrol-I - yl)-5-sulfonamido-I,3,4-thiadiazole (8b)}

To a solution of 2-amino-5-sulfonamido-1,3,4-thiadiazole $(10 \mathrm{mmol})$ in $20 \mathrm{~mL}$ glacial acetic acid, acetonyl acetone (15 mmol) was added slowly at room temperature and was refluxed for 30 minutes. The reaction mixture was poured into ice-cold water and basified with sodium bicarbonate solution. The separated solid was collected, washed with water, dried, and recrystallized from ethanol.

Yield, 30\%: $\mathrm{mp} 206^{\circ} \mathrm{C}-208^{\circ} \mathrm{C}$; FTIR (KBr): 3,274.75, 3,085.68 $\left(\mathrm{SO}_{2} \mathrm{NH}_{2}\right), 2,773.97(\mathrm{Ar}-\mathrm{H}), 1,513.63(\mathrm{C}=\mathrm{N})$
$1,316.14\left(\mathrm{SO}_{2}{ }^{\text {as }}\right), 1,129.71\left(\mathrm{SO}_{2}{ }^{\mathrm{sym}}\right) \mathrm{cm}^{-1} ;{ }^{1} \mathrm{H}$ NMR (400 $\left.\mathrm{MHz}, \mathrm{CDCl}_{3}\right) \delta$ ppm: $1.80\left(\mathrm{~s}, 6 \mathrm{H}\right.$, pyrrole- $\left.2 \mathrm{CH}_{3}\right), 5.60(\mathrm{~s}, 2 \mathrm{H}$, pyrrole- $\mathrm{C}_{3}$ and $\left.\mathrm{C}_{4}-\mathrm{H}\right), 8.52\left(\mathrm{~s}, 2 \mathrm{H}, \mathrm{NH}_{2}\right) ;{ }^{13} \mathrm{C} \mathrm{NMR}(400 \mathrm{MHz}$, $\left.\mathrm{CDCl}_{3}\right) \delta$ ppm: $12.81\left(2 \mathrm{CH}_{3}\right), 115.23$ (pyrrole- $\mathrm{C}_{3}$ and $\mathrm{C}_{4}$ ), 121.98 (pyrrole- $\mathrm{C}_{2}$ and $\mathrm{C}_{5}$ ), 164.88 (thiadiazole- $\mathrm{C}_{2}$ ), 166.03 (thiadiazole- $\mathrm{C}_{5}$ ); MS (EI): $\mathrm{m} / \mathrm{z}=$ found $258.19\left[\mathrm{M}^{+}\right]$; calcd. 258.02. Anal. $\mathrm{C}_{8} \mathrm{H}_{10} \mathrm{~N}_{4} \mathrm{O}_{2} \mathrm{~S}_{2}$.

\section{Biological evaluation}

\section{Antitubercular activity}

The MIC values were determined for the newly synthesized compounds (4a-4i, 5a-5i, and 8a-8b) against M. tuberculosis strain $\mathrm{H}_{37} \mathrm{Rv}$, using a microplate Alamar blue assay. ${ }^{33}$ Isoniazid was used as the standard drug. The 96-well plate received $100 \mu \mathrm{L}$ of the Middlebrook 7H9 broth, and serial dilution of compounds was made directly on the plate. The final drug concentrations tested were $0.2,0.4,0.8,1.6,3.125,6.25,12.5,25$, 50 , and $100 \mu \mathrm{g} \mathrm{mL}^{-1}$. Plates were covered and sealed with parafilm and incubated at $37^{\circ} \mathrm{C}$ for 5 days. After this, $25 \mu \mathrm{L}$ freshly prepared 1:1 mixture of Alamar blue reagent and 10\% Tween 80 was added to the plate and incubated for 24 hours. A blue color in the well was interpreted as no bacterial growth, and a pink color was scored as the growth. The MIC was defined as the lowest drug concentration that prevented the color change from blue to pink. Table 1 reveals the antitubercular activity (MIC) data of the newly synthesized compounds.

\section{Molecular modeling}

\section{General procedure}

The 3D structure building and all modeling protocols were performed using the Sybyl-X 2.0 programming package running on a dual-core Intel core i3-2130 CPU $3.40 \mathrm{GHz}$, RAM Memory 2 GB workstation running Windows 7. Each structure was geometrically optimized using a conjugate gradient method based on Tripos force field ${ }^{34}$ and MMFF94 charge, with a distance-dependant dielectric and Powell conjugate gradient algorithm with a convergence criterion of 0.01 $\mathrm{kcal} / \mathrm{mol}$. Partial atomic charges were calculated using the semiempirical program MOPAC 6.0, as well as by applying the AM1 Hamiltonian (Austin Model 1). ${ }^{35}$

\section{Protein preparation}

Crystal structure of M. tuberculosis enoyl reductase (InhA) complexed with 1-cyclohexyl- $N$-(3,5-dichlorophenyl)-5oxopyrrolidine-3-carboxamide was retrieved from Research Collaboratory for Structural Bioinformatics Protein Data Bank (PDB ID code 4TZK). ${ }^{12}$ Water molecules were removed, and essential hydrogens were added; united atoms 

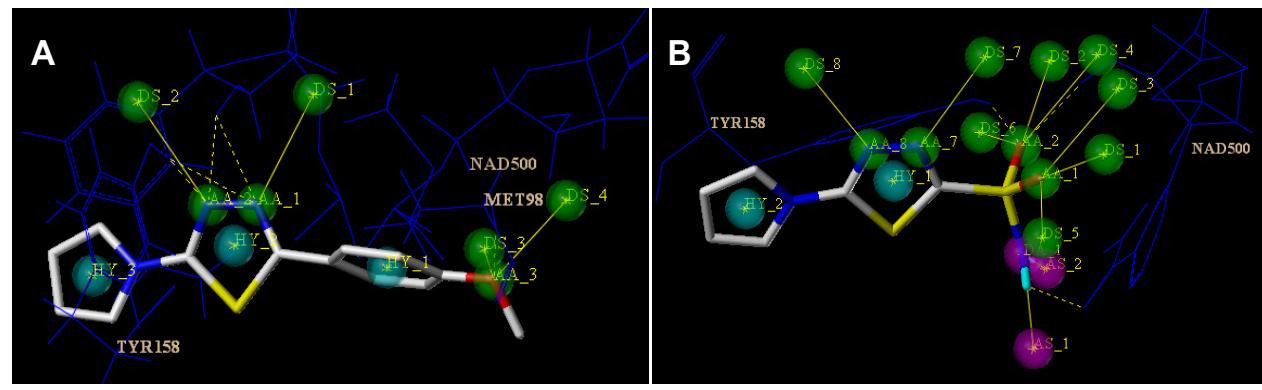

Figure I4 Pharmacophoric and receptor binding features (cyan, hydrophobic; green, H-bond acceptor; magenta, H-bond donor) for compounds 4b (A) and 8a (B) (capped sticks model in atom type color).

Amber7FF9902 were assigned for the protein. Geometry optimization was carried out using the standard Tripos force field, with a distance-dependent dielectric function keeping the energy gradient of $0.001 \mathrm{kcal} / \mathrm{mol}$. Surflex-Dock is one of the best docking suites employed for docking analysis. ${ }^{36,37}$

\section{Conclusion}

Most of the synthesized compounds exhibited moderate activity against $M$. tuberculosis. Compounds $4 \mathrm{~b}, 5 \mathrm{~b}$, and $5 \mathrm{~d}$ inhibited growth of $M$. tuberculosis very effectively at a MIC value of $12.5 \mu \mathrm{g} / \mathrm{mL}$, followed by compounds $4 \mathrm{~d}$, $4 \mathrm{~h}$, $4 \mathrm{i}, 5 \mathrm{~h}, 5 \mathrm{i}, 8 \mathrm{a}$, and $8 \mathrm{~b}$, with MIC values $25 \mu \mathrm{g} / \mathrm{mL}$. Most of the molecules could effectively bind to the substrate binding site of ENR. The key H-bonding interactions with Tyr158, Met98, and cofactor $\mathrm{NAD}^{+}$, as well as hydrophobic amino acid residues, stabilized the ligand-receptor complex to conclude that molecules are efficiently bound at the active site of ENR and, hence, can be better ENR inhibitors. To accomplish the inhibitory action, H-bond acceptor atoms and hydrophobic fragments played a key role (Figure 14). The predicted in silico Surflex-Dock values obtained through docking studies have pointed toward 4b, 5d, and $8 \mathrm{a}$ as the most promising inhibitors. Conclusively, compounds substituted with $-\mathrm{OCH}_{3},-\mathrm{NO}_{2},-\mathrm{F}$, pyridine, and sulfonamide groups or moieties were found to be better inhibitors than compounds substituted with $-\mathrm{CH}_{3},-\mathrm{NH}_{2},-\mathrm{Cl}$, and $-\mathrm{Br}$ groups. All the synthesized compounds showed a reasonable correlation between the experimental and predicted results. The present study suggests that molecular docking and in vitro MIC assay analysis could serve to be an efficient prescreening technique for identifying new ENR inhibitors and may be useful in situations in which enzyme inhibition experimental data are insufficient or not available.

\section{Acknowledgments}

We thank the Indian Council of Medical Research, New Delhi, India, for financial support (File 64/4/2011-BMS,
IRIS Cell 2010-08710) and acknowledge partial financial support from the Vision Group on Science and Technology, Department of Information Technology, Biotechnology and Science and Technology, Dr S Ananth Raj, Bangalore (File VGST/P-3/SMYSR/GRD-277/2013-14/, dated January 28, 2014). We also thank Mr HV Dambal, president and Dr VH Kulkarni, principal, Soniya Education Trust's College of Pharmacy, Dharwad, India, for providing facilities. We thank Dr KG Bhat, Maratha Mandal's Dental College, Hospital and Research Centre, Belgaum, India, for providing facilities for antitubercular activity. The director, Sophisticated Analytical Instrument Facility (SAIF), Indian Institute of Technology, Chennai, Tamil Nadu, India, and the director, SAIF, Panjab University, Chandigarh, Panjab, India, have provided NMR and mass spectral data. We also thank Mr Shrikant A Tiwari for his technical assistance.

\section{Disclosure}

The authors report no conflicts of interest in this work.

\section{References}

1. Bogatcheva E, Hanrahan C, Nikonenko B, et al. Identification of new diamine scaffolds with activity against Mycobacterium tuberculosis. J Med Chem. 2006;49(11):3045-3048.

2. Rattan A, Kalia A, Ahmad N. Multidrug-resistant Mycobacterium tuberculosis: molecular perspectives. Emerg Infect Dis. 1998;4(2): 195-209.

3. Bloch K. Control mechanisms for fatty acid synthesis in Mycobacterium smegmatis. Adv Enzymol Relat Areas Mol Biol. 1977;45:1-84.

4. Kikuchi S, Rainwater DL, Kolattukudy PE. Purification and characterization of an unusually large fatty acid synthase from Mycobacterium tuberculosis var. bovis BCG. Arch. Biochem Biophys. 1992;295(2): 318-326.

5. Qureshi N, Sathyamoorthy N, Takayama K. Biosynthesis of C30 to C56 fatty acids by an extract of Mycobacterium tuberculosis H37Ra. J Bacteriol. 1984;157(1):46-52.

6. Brennan PJ, Nikaido H. The envelope of mycobacteria. Annu Rev Biochem. 1995;64(1):29-63.

7. Lee RE, Brennan PJ, Besra GS. Mycobacterium tuberculosis cell envelope. Curr Top Microbiol Immunol. 1996;215:1-27.

8. Banerjee A, Dubnau E, Quemard A, et al. inhA, a gene encoding a target for isoniazid and ethionamide in Mycobacterium tuberculosis. Science. 1994;263(5144):227-230. 
9. Wang F, Langley R, Gulten G, et al. Mechanism of thioamide drug action against tuberculosis and leprosy. J Exp Med. 2007;204(1):73-78.

10. Kuo MR, Morbidoni HR, Alland D, et al. Targeting tuberculosis and malaria through inhibition of Enoyl reductase: compound activity and structural data. J Biol Chem. 2003;278(23):20851-20859.

11. Sullivan TJ, Truglio JJ, Boyne ME, et al. High affinity InhA inhibitors with activity against drug-resistant strains of Mycobacterium tuberculosis. ACS Chem Biol. 2006;1(1):43-53.

12. He X, Alian A, Stroud R, Ortiz de Montellano PR. Pyrrolidine carboxamides as a novel class of inhibitors of enoyl acyl carrier protein reductase from Mycobacterium tuberculosis. J Med Chem. 2006;49(21): 6308-6323.

13. Joshi SD, More UA, Kulkarni VH, Aminabhavi TM. Pyrrole: chemical synthesis, microwave assisted synthesis, reactions and applications: A review. Curr Org Chem. 2013;17(20):2279-2304.

14. Bhat AR, Tazeem, Azam A, Choi I, Athar F. 3-(1,3,4-Thiadiazole-2-yl) quinoline derivatives: synthesis, characterization and anti-microbial activity. Eur J Med Chem. 2011;46(7):3158-3166.

15. Talath $S$, Gadad AK. Synthesis, antibacterial and antitubercular activities of some 7-[4-(5-amino-[1,3,4] thiadiazole-2-sulfonyl)-piperazin-1-yl] fluoroquinolonic derivatives. Eur J Med Chem. 2006;41(8):918-924.

16. Foroumadi A, Kargar Z, Sakhteman A, et al. Synthesis and antimycobacterial activity of some alkyl [5-(nitroaryl)-1,3,4-thiadiazol-2-ylthio] propionates. Bioorg Med Chem Lett. 2006;16(5):1164-1167.

17. More UA, Joshi SD, Aminabhavi TM, Gadad AK, Nadagouda MN, Kulkarni VH. Design, synthesis, molecular docking and 3D-QSAR studies of potent inhibitors of enoyl-acyl carrier protein reductase as potential antimycobacterial agents. Eur J Med Chem. 2014;71:199-218.

18. More UA, Joshi SD, Kulkarni VH. Antitubercular activity of pyrrole Schiff bases and computational study of M. tuberculosis InhA. Int J Drug Design Disc. 2013;4:1163-1173.

19. Joshi SD, More UA, Aminabhavi TM, Badiger AM. Two- and threedimensional QSAR studies on a set of antimycobacterial pyrroles: CoMFA, Topomer CoMFA, and HQSAR. Med Chem Res. 2014;23(1): $107-126$.

20. Joshi SD, More UA, Dixit SR, Korat HH, Aminabhavi TM, Badiger AM. Synthesis, characterization, biological activity, and 3D-QSAR studies on some novel class of pyrrole derivatives as antitubercular agents. Med Chem Res. 2014;23(3):1123-1147.

21. Joshi SD, Dixit SR, More UA, Devendra K, AminabhaviTM, Kulkarni VH. 3D-QSAR studies of quinoline Schiff bases as enoyl acyl carrier protein reductase inhibitors. Res Rep Med Chem. 2014;4:59-75.

22. Bukhari SN, Franzblau SG, Jantan I, Jasamai M. Current prospects of synthetic curcumin analogs and chalcone derivatives against Mycobacterium tuberculosis. Med Chem. 2013;9(7):897-903.

23. Joshi SD, Joshi A, Vagdevi HM, Vaidya VP, Gadaginamath GS. Synthesis and antimicrobial evaluation of some new pyrrolylnaphtho[2,1-b] furan derivatives. Indian J Pharm Educ Res. 2010;44:148-155.
24. Joshi SD, Joshi A, Vagdevi HM, Vaidya VP, Gadaginamath GS. Microwave assisted synthesis of some new quinolinylpyrrole derivatives as potential antibacterial and antitubercular agents. Indian J Heterocycl Chem. 2010;19:221-224.

25. Joshi SD, More Y, Vagdevi HM, Vaidya VP, Gadaginamath GS, Kulkarni VH. Synthesis of new 4-(2,5-dimethylpyrrol-1-yl)/4pyrrol-1-yl benzoic acid hydrazide analogs and some derived oxadiazole, triazole and pyrrole ring systems a novel class of potential antibacterial, antifungal and antitubercular agents. Med Chem Res. 2013;22(3):1073-1089.

26. Joshi SD, Manish K, Badiger A. Synthesis and evaluation of antibacterial and antitubercular activities of some novel imidazo[2,1-b][1,3,4] thiadiazole derivatives. Med Chem Res. 2013;22(2):869-878.

27. Joshi SD, Vagdevi HM, Vaidya VP, Gadaginamath GS. Synthesis of new 4-pyrrol-1-yl benzoic acid hydrazide analogs and some derived oxadiazole, triazole and pyrrole ring systems,: a novel class of potential antibacterial and antitubercular agents. Eur J Med Chem. 2008;43(9): 1989-1996.

28. Kitchen DB, Decornez H, Furr JR, Bajorath J. Docking and scoring in virtual screening for drug discovery: methods and applications. Nat Rev Drug Discov. 2004;3(11):935-949.

29. Ho CM, Marshall GR. Cavity search: an algorithm for the isolation and display of cavity-like binding regions. J Comput Aided Mol Des. 1990;4(4):337-354.

30. Jain AN. Scoring noncovalent protein-ligand interactions: a continuous differentiable function tuned to compute binding affinities. $J$ Comput Aided Mol Des. 1996;10(5):427-440.

31. Jain AN. Surflex: fully automatic flexible molecular docking using a molecular similarity-based search engine. J Med Chem. 2003;46(4): 499-511.

32. Tu G, Li S, Huang H, et al. Novel aminopeptidase $\mathrm{N}$ inhibitors derived from 1,3,4-thiadiazole scaffold. Bioorg Med Chem. 2008;16(14): 6663-6668.

33. Franzblau SG, Witzig RS, McLaughlin JC, et al. Rapid, low-technology MIC determination with clinical Mycobacterium tuberculosis isolates by using the microplate Alamar Blue assay. J Clin Microbiol. 1998;36(2): 362-366.

34. Clark M, Cramer RD III, Opdenbosch NV. Validation of the general purpose tripos 5.2 forcefield. J Comput Chem. 1989;10(8):982-1012.

35. Stewart JJ. ; StewartJJ. MOPAC: a semiempirical molecular orbital program. $J$ Comput Aided Mol Des. 1990;4(1):1-105.

36. Spitzer R, Jain AN. Surflex-Dock: docking benchmarks and real-world application. J Comput Aided Mol Des. 2012;26(6):687-699.

37. Pham TA, Jain AN. Customizing scoring functions for docking. J Comput Aided Mol Des. 2008;22(5):269-286. 


\section{Supplementary materials \\ Pharmacophore mapping}

During the study, it was found that the InhA inhibitor [1-cyclohexyl- $N$-(3,5-dichlorophenyl)-5-oxopyrrolidine3-carboxamide (pyrrolidine carboxamide or 641)], which contains three hydrophobic moieties, such as cyclohexyl, oxopyrrolidine, and 3,5-dichlorophenyl, can be replaced by new, designed molecules, which contain pyrrole, 1,3,4-thiadiazole, and substituted phenyl. Hydrogen bond acceptor atoms such as oxygen at the fifth position of pyrrolidine and nitrogens at 1,3,4-thiadiazole make an H-bond with key amino acid Tyr158 and cofactor NAD ${ }^{+}$, which helps in structure-based drug design and the selection of target.

\section{Hydropathy plots}

In hydropathy, produce scatter plots of the hydropathy indices as a function of the residue number. Such plots are frequently used to identify segments of a protein sequence that have hydrophobic properties consistent with a transmembrane helix.

Three columns are added to the spreadsheet: HYDRO is the hydrophobicity at each residue, with its value depending on the hydrophobicity scale chosen. HYD_5 is the hydropathy index averaged over a moving window of eleven residues (five on either side of a given residue). The window size determines the extent of smoothing for the calculation of hydropathy indices. SEQNUM is an integer corresponding to the serial position of the residue in the protein. It is a useful index when residue numbering does not start at one or is not sequential.

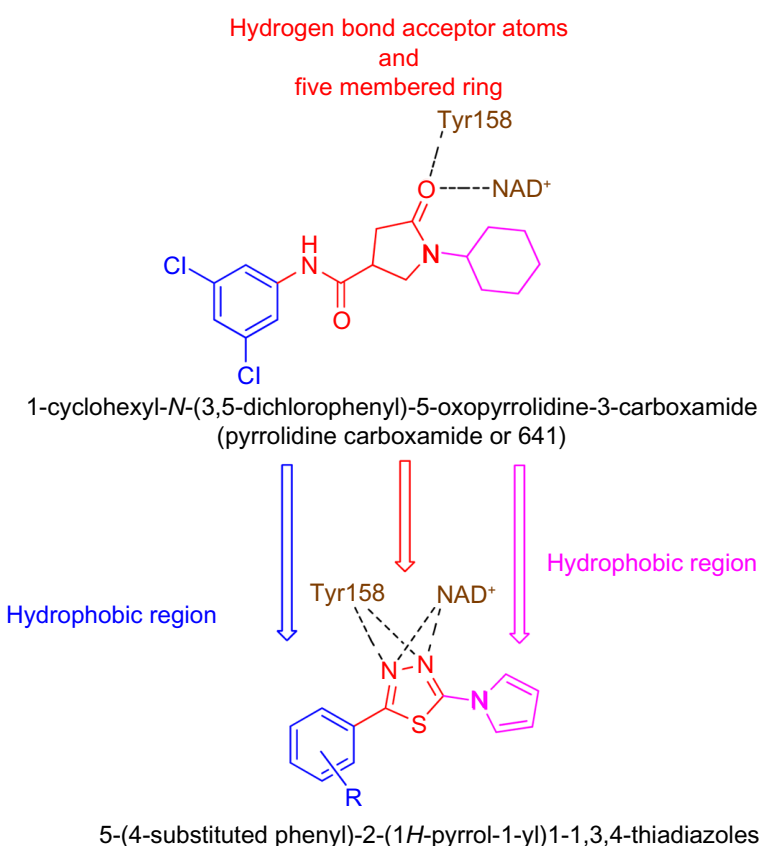

Figure SI Structure-based drug design concept. 
Table SI Hydrophobicity scales for protein

\begin{tabular}{|c|c|c|c|c|c|c|c|}
\hline Name & HYDRO & HYD_5 & SEQNUM & Name & HYDRO & HYD_5 & SEQNUM \\
\hline AMNI & - & - & 1 & PROI36 & -1.6 & 0.6 & 136 \\
\hline THR2 & -0.7 & - & 2 & ILEI37 & 4.5 & 0.4 & 137 \\
\hline GLY3 & -0.4 & - & 3 & METI 38 & 1.9 & 0.6818 & 138 \\
\hline LEU4 & 3.8 & - & 4 & ASNI 39 & -3.5 & 0.9273 & 139 \\
\hline LEU5 & 3.8 & - & 5 & PROI40 & -1.6 & 0.9636 & 140 \\
\hline ASP6 & -3.5 & 0.2273 & 6 & GLYI4I & -0.4 & 0.5818 & 141 \\
\hline GLY7 & -0.4 & 0.6091 & 7 & GLYI42 & -0.4 & 0.9 & 142 \\
\hline LYS8 & -3.9 & 0.6 & 8 & SERI43 & -0.8 & 0.1727 & 143 \\
\hline ARG9 & -4.5 & 0.6 & 9 & ILEI44 & 4.5 & 0.2545 & 144 \\
\hline ILEIO & 4.5 & 0.6636 & 10 & VALI 45 & 4.2 & 0.2545 & 145 \\
\hline LEUII & 3.8 & 0.7273 & 11 & GLYI46 & -0.4 & 0.2545 & 146 \\
\hline VALI2 & 4.2 & 0.9818 & 12 & METI47 & 1.9 & 0.2182 & 147 \\
\hline SERI3 & -0.8 & 0.7 & 13 & ASPI48 & -3.5 & -0.1545 & 148 \\
\hline GLYI4 & -0.4 & 0.9818 & 14 & PHEI 49 & 2.8 & 0.0818 & 149 \\
\hline ILEI5 & 4.5 & 1.3182 & 15 & ASPI50 & -3.5 & -0.1545 & 150 \\
\hline ILEI6 & 4.5 & 1.3182 & 16 & PROI5I & -1.6 & -0.6818 & $15 \mid$ \\
\hline THRI7 & -0.7 & 1.1364 & 17 & SERI52 & -0.8 & -0.4818 & 152 \\
\hline ASPI8 & -3.5 & $1.009 \mid$ & 18 & ARGI53 & -4.5 & -0.7727 & 153 \\
\hline SERI9 & -0.8 & 0.7909 & 19 & ALA I 54 & 1.8 & -0.7727 & 154 \\
\hline SER20 & -0.8 & 1.2364 & 20 & METI55 & 1.9 & -1.1091 & 155 \\
\hline ILE2I & 4.5 & 0.9909 & 21 & PROI56 & -1.6 & -0.6182 & 156 \\
\hline ALA22 & 1.8 & 0.1727 & 22 & ALAI 57 & 1.8 & -0.5364 & 157 \\
\hline PHE23 & 2.8 & 0.6182 & 23 & TYRI58 & -1.3 & -0.0818 & 158 \\
\hline HIS24 & -3.2 & 1.1 & 24 & ASNI59 & -3.5 & 0.4909 & 159 \\
\hline ILE25 & 4.5 & 0.8545 & 25 & TRPI60 & -0.9 & -0.0273 & 160 \\
\hline ALA26 & 1.8 & 0.6091 & 26 & METI6I & 1.9 & -0.2727 & 161 \\
\hline ARG27 & -4.5 & -0.1182 & 27 & THRI62 & -0.7 & 0.0364 & 162 \\
\hline VAL28 & 4.2 & -0.3182 & 28 & VALI 63 & 4.2 & 0.2182 & 163 \\
\hline ALA29 & 1.8 & -0.4091 & 29 & ALAI 64 & 1.8 & 0.0182 & 164 \\
\hline GLN30 & -3.5 & -0.4364 & 30 & LYSI65 & -3.9 & 0.2636 & 165 \\
\hline GLU3I & -3.5 & -0.5 & 31 & SERI 66 & -0.8 & 0.7273 & 166 \\
\hline GLN32 & -3.5 & -0.2818 & 32 & ALAI 67 & 1.8 & 0.2364 & 167 \\
\hline GLY33 & -0.4 & 0.4727 & 33 & LEUI68 & 3.8 & -0.1091 & 168 \\
\hline ALA34 & 1.8 & 0.0273 & 34 & GLUI69 & -3.5 & -0.2364 & 169 \\
\hline GLN35 & -3.5 & -0.1727 & 35 & SERI70 & -0.8 & -0.0182 & 170 \\
\hline LEU36 & 3.8 & 0.4 & 36 & VALI7I & 4.2 & 0.5 & $17 \mid$ \\
\hline VAL37 & 4.2 & 0.4 & 37 & ASNI72 & -3.5 & 0.1636 & 172 \\
\hline LEU38 & 3.8 & 0.3091 & 38 & ARGI73 & -4.5 & -0.3182 & 173 \\
\hline THR39 & -0.7 & 0.6909 & 39 & PHEI74 & 2.8 & -0.5 & 174 \\
\hline GLY40 & -0.4 & 0.1182 & 40 & VALI 75 & 4.2 & -0.2182 & 175 \\
\hline PHE4I & 2.8 & 0.7818 & 41 & ALAI 76 & 1.8 & -0.5 & 176 \\
\hline ASP42 & -3.5 & 0.8455 & 42 & ARGI77 & -4.5 & -1 & 177 \\
\hline ARG43 & -4.5 & 0.1455 & 43 & GLUI78 & -3.5 & -0.7182 & 178 \\
\hline LEU44 & 3.8 & -0.6091 & 44 & ALAI 79 & 1.8 & 0.0727 & 179 \\
\hline ARG45 & -4.5 & -0.1364 & 45 & GLYI80 & -0.4 & -0.5909 & 180 \\
\hline LEU46 & 3.8 & -0.1636 & 46 & LYSI8I & -3.9 & -1.0455 & 181 \\
\hline ILE47 & 4.5 & -0.7364 & 47 & TYRI 82 & -1.3 & -1.5273 & 182 \\
\hline GLN48 & -3.5 & -0.8273 & 48 & GLYI83 & -0.4 & -0.7727 & 183 \\
\hline ARG49 & -4.5 & -0.0727 & 49 & VALI84 & 4.2 & -0.0727 & 184 \\
\hline ILE50 & 4.5 & -0.5636 & 50 & ARG I 85 & -4.5 & -0.0727 & 185 \\
\hline THR5I & -0.7 & 0.0091 & 51 & SERI 86 & -0.8 & 0.1273 & 186 \\
\hline ASP52 & -3.5 & -0.6909 & 52 & ASNI87 & -3.5 & 0.4455 & 187 \\
\hline ARG53 & -4.5 & -0.9364 & 53 & LEUI 88 & 3.8 & 0.4182 & 188 \\
\hline LEU54 & 3.8 & -0.7636 & 54 & VALI89 & 4.2 & 0.8636 & 189 \\
\hline
\end{tabular}


Table SI (Continued)

\begin{tabular}{|c|c|c|c|c|c|c|c|}
\hline Name & HYDRO & HYD_5 & SEQNUM & Name & HYDRO & HYD_5 & SEQNUM \\
\hline PRO55 & -1.6 & -0.0091 & 55 & ALA 190 & 1.8 & 0.0727 & 190 \\
\hline ALA56 & 1.8 & -0.0727 & 56 & ALAI9I & 1.8 & 0.4182 & 191 \\
\hline LYS57 & -3.9 & -0.3273 & 57 & GLYI92 & -0.4 & 0.8364 & 192 \\
\hline ALA58 & 1.8 & 0.3364 & 58 & PROI93 & -1.6 & 1.3182 & 193 \\
\hline PRO59 & -1.6 & 0.4273 & 59 & ILEI94 & 4.5 & 1.1455 & 194 \\
\hline LEU60 & 3.8 & 0.4636 & 60 & ARGI95 & -4.5 & 0.6909 & 195 \\
\hline LEU6I & 3.8 & 0.2909 & 61 & THRI96 & -0.7 & 0.6909 & 196 \\
\hline GLU62 & -3.5 & -0.1909 & 62 & LEUI97 & 3.8 & 0.9364 & 197 \\
\hline LEU63 & 3.8 & -0.1545 & 63 & ALAI98 & 1.8 & 1.3545 & 198 \\
\hline ASP64 & -3.5 & -0.6364 & 64 & METI99 & 1.9 & 1.4636 & 199 \\
\hline VAL65 & 4.2 & -0.7818 & 65 & SER200 & -0.8 & 1.0182 & 200 \\
\hline GLN66 & -3.5 & -0.7818 & 66 & ALA20 I & 1.8 & 1.5909 & 201 \\
\hline ASN67 & -3.5 & -0.9636 & 67 & ILE202 & 4.5 & 2 & 202 \\
\hline GLU68 & -3.5 & -0.7182 & 68 & VAL203 & 4.2 & 1.6182 & 203 \\
\hline GLU69 & -3.5 & -0.7182 & 69 & GLY204 & -0.4 & 1.1364 & 204 \\
\hline HIS70 & -3.2 & -0.2364 & 70 & GLY205 & -0.4 & 0.6455 & 205 \\
\hline LEU7I & 3.8 & -0.6545 & 71 & ALA206 & 1.8 & 0.8818 & 206 \\
\hline ALA72 & 1.8 & -0.7455 & 72 & LEU207 & 3.8 & 0.6818 & 207 \\
\hline SER73 & -0.8 & -0.0455 & 73 & GLY208 & -0.4 & 0.4364 & 208 \\
\hline LEU74 & 3.8 & 0.2091 & 74 & GLU209 & -3.5 & -0.2636 & 209 \\
\hline ALA75 & 1.8 & 0.2091 & 75 & GLU210 & -3.5 & 0.1818 & 210 \\
\hline GLY76 & -0.4 & 0.6636 & 76 & ALA2II & 1.8 & -0.1 & 211 \\
\hline ARG77 & -4.5 & 0.7273 & 77 & GLY2I2 & -0.4 & 0.0818 & 212 \\
\hline VAL78 & 4.2 & 0.5273 & 78 & ALA2I 3 & 1.8 & 0.0818 & 213 \\
\hline THR79 & -0.7 & 0.7636 & 79 & GLN2I 4 & -3.5 & -0.2 & 214 \\
\hline GLU80 & -3.5 & 0.3818 & 80 & ILE2I5 & 4.5 & -0.2 & 215 \\
\hline ALA8I & 1.8 & -0.1 & 81 & GLN216 & -3.5 & 0.0818 & 216 \\
\hline ILE82 & 4.5 & -0.4182 & 82 & LEU2I 7 & 3.8 & -0.1636 & 217 \\
\hline GLY83 & -0.4 & 0.3364 & 83 & LEU2। 8 & 3.8 & -0.4455 & 218 \\
\hline ALA84 & 1.8 & -0.3636 & 84 & GLU219 & -3.5 & -0.9273 & 219 \\
\hline GLY85 & -0.4 & -0.3364 & 85 & GLU220 & -3.5 & -1.0182 & 220 \\
\hline ASN86 & -3.5 & 0.3636 & 86 & GLY22I & -0.4 & -1.2636 & 221 \\
\hline LYS87 & -3.9 & 0.5818 & 87 & TRP222 & -0.9 & -1.0909 & 222 \\
\hline LEU88 & 3.8 & -0.1182 & 88 & ASP223 & -3.5 & -1.0273 & 223 \\
\hline ASP89 & -3.5 & -0.1545 & 89 & GLN224 & -3.5 & $-1.409 \mid$ & 224 \\
\hline GLY90 & -0.4 & 0.0909 & 90 & ARG225 & -4.5 & -1.1727 & 225 \\
\hline VAL9I & 4.2 & 0.0909 & 91 & ALA226 & 1.8 & -1.1727 & 226 \\
\hline VAL92 & 4.2 & 0.6636 & 92 & PRO227 & -1.6 & -0.9636 & 227 \\
\hline HIS93 & -3.2 & 1.1909 & 93 & ILE228 & 4.5 & -1.2364 & 228 \\
\hline SER94 & -0.8 & 0.7 & 94 & GLY229 & -0.4 & -1.2364 & 229 \\
\hline ILE95 & 4.5 & 0.7 & 95 & TRP230 & -0.9 & -0.7545 & 230 \\
\hline GLY96 & -0.4 & 0.6727 & 96 & ASN23I & -3.5 & -0.4091 & 231 \\
\hline PHE97 & 2.8 & 0.2545 & 97 & MET232 & 1.9 & -0.7182 & 232 \\
\hline MET98 & 1.9 & 0.0455 & 98 & LYS233 & -3.9 & -0.1909 & 233 \\
\hline PRO99 & -1.6 & 0.3 & 99 & ASP234 & -3.5 & -0.4364 & 234 \\
\hline GLNIO0 & -3.5 & 0.7818 & 100 & ALA235 & 1.8 & -0.7545 & 235 \\
\hline THRIOI & -0.7 & 0.0545 & 101 & THR236 & -0.7 & -0.7364 & 236 \\
\hline GLYI02 & -0.4 & -0.0545 & 102 & PRO237 & -1.6 & -0.0364 & 237 \\
\hline METI03 & 1.9 & -0.0545 & 103 & VAL238 & 4.2 & 0.0182 & 238 \\
\hline GLYI04 & -0.4 & 0.0273 & 104 & ALA239 & 1.8 & 0.5364 & 239 \\
\hline ILEI05 & 4.5 & -0.1455 & 105 & LYS240 & -3.9 & 1.2 & 240 \\
\hline ASNIO6 & -3.5 & 0.3364 & 106 & THR24I & -0.7 & 1.3818 & 241 \\
\hline PROI07 & -1.6 & 0.2545 & 107 & VAL242 & 4.2 & 1.3727 & 242 \\
\hline PHEI08 & 2.8 & 0.1727 & 108 & CYS243 & 2.5 & 1.2 & 243 \\
\hline
\end{tabular}


Table SI (Continued)

\begin{tabular}{|c|c|c|c|c|c|c|c|}
\hline Name & HYDRO & HYD_5 & SEQNUM & Name & HYDRO & HYD_5 & SEQNUM \\
\hline PHEI09 & 2.8 & 0.1636 & 109 & ALA244 & 1.8 & 0.7364 & 244 \\
\hline ASPIIO & -3.5 & -0.1182 & 110 & LEU245 & 3.8 & 0.9182 & 245 \\
\hline ALA I II & 1.8 & -0.1455 & 111 & LEU246 & 3.8 & I. 1273 & 246 \\
\hline PROII2 & -1.6 & 0.1 & 112 & SER247 & -0.8 & 1.3545 & 247 \\
\hline TYRII3 & -1.3 & -0.1091 & 113 & ASP248 & -3.5 & 0.9091 & 248 \\
\hline ALAII 4 & 1.8 & -0.4 & 114 & TRP249 & -0.9 & 0.6182 & 249 \\
\hline ASPII5 & -3.5 & -0.2455 & 115 & LEU250 & 3.8 & 0.4182 & 250 \\
\hline VALII 6 & 4.2 & -0.2182 & 116 & PRO25I & -1.6 & -0.2455 & 251 \\
\hline SERII7 & -0.8 & 0.0273 & 117 & ALA252 & 1.8 & -0.1818 & 252 \\
\hline LYSII8 & -3.9 & 0.1 & 118 & THR253 & -0.7 & 0.3 & 253 \\
\hline GLYII9 & -0.4 & 0.3818 & 119 & THR254 & -0.7 & 0.5 & 254 \\
\hline ILEI 20 & 4.5 & 0.1 & 120 & GLY255 & -0.4 & 0.7455 & 255 \\
\hline HISI2I & -3.2 & 0.3455 & 121 & ASP256 & -3.5 & 0.0818 & 256 \\
\hline ILEI 22 & 4.5 & -0.1545 & 122 & ILE257 & 4.5 & 0.1909 & 257 \\
\hline SERI23 & -0.8 & 0.0818 & 123 & ILE258 & 4.5 & -0.0091 & 258 \\
\hline ALAI 24 & 1.8 & 0.3636 & 124 & TYR259 & -1.3 & 0.2182 & 259 \\
\hline TYRI25 & -1.3 & 0.5727 & 125 & ALA260 & 1.8 & -0.0091 & 260 \\
\hline SERI 26 & -0.8 & 0.3273 & 126 & ASP26I & -3.5 & -0.0364 & 261 \\
\hline TYRI27 & -1.3 & 0.2636 & 127 & GLY262 & -0.4 & -0.0364 & 262 \\
\hline ALAI 28 & 1.8 & 0.0182 & 128 & GLY263 & -0.4 & -0.1 & 263 \\
\hline SERI29 & -0.8 & 0.4364 & 129 & ALA264 & 1.8 & -0.1636 & 264 \\
\hline METI 30 & 1.9 & 0.6182 & 130 & HIS265 & -3.2 & -0.0455 & 265 \\
\hline ALAI3I & 1.8 & 0.5909 & $13 \mid$ & THR266 & -0.7 & - & 266 \\
\hline LYSI 32 & -3.9 & 1.0727 & 132 & GLN267 & -3.5 & - & 267 \\
\hline ALAI33 & 1.8 & 1.3636 & 133 & LEU268 & 3.8 & - & 268 \\
\hline LEUI 34 & 3.8 & 0.8818 & 134 & LEU269 & 3.8 & - & 269 \\
\hline LEUI 35 & 3.8 & 0.8091 & 135 & CXL270 & - & - & 270 \\
\hline
\end{tabular}

Notes: HYDRO, hydrophobicity at each residue, with value depending on the hydrophobicity scale chosen; HYD_5, the hydropathy index averaged over a moving window of eleven residues (five on either side of a given residue), and is the window size that determines the extent of smoothing for the calculation of hydropathy indices; SEQNUM, an integer corresponding to the serial position of the residue in the protein. It is a useful index when residue numbering does not start at one or is not sequential.

\section{Publish your work in this journal}

Research and Reports in Medicinal Chemistry is an international, peerreviewed, open access journal publishing original research, reports, reviews and commentaries on all areas of medicinal chemistry. The manuscript management system is completely online and includes a very quick and fair peer-review system, which is all easy to use.
Visit http://www.dovepress.com/testimonials.php to read real quotes from published authors. 